\title{
Mammalian sphingosine kinase (SphK) isoenzymes and isoform expression: challenges for SphK as an oncotarget
}

\author{
Diana Hatoum ${ }^{1, *}$, Nahal Haddadi ${ }^{1, *}$, Yiguang Lin ${ }^{1}$, Najah T. Nassif ${ }^{1}$ and Eileen M. \\ McGowan'1 \\ ${ }^{1}$ School of Life Sciences, University of Technology Sydney, Ultimo, Sydney, NSW 2007, Australia \\ * These authors have contributed equally to this manuscript \\ Correspondence to: Eileen M. McGowan, email: Eileen.mcgowan@uts.edu.au \\ Keywords: sphingosine kinase, isoenzymes, isoforms, cancer, sphingosine-1-phosphate \\ Received: January 06, $2017 \quad$ Accepted: March 02, $2017 \quad$ Published: March 18, 2017
}

Copyright: Hatoum et al. This is an open-access article distributed under the terms of the Creative Commons Attribution License (CC-BY), which permits unrestricted use, distribution, and reproduction in any medium, provided the original author and source are credited.

\section{ABSTRACT}

The various sphingosine kinase (SphK) isoenzymes (isozymes) and isoforms, key players in normal cellular physiology, are strongly implicated in cancer and other diseases. Mutations in SphKs, that may justify abnormal physiological function, have not been recorded. Nonetheless, there is a large and growing body of evidence demonstrating the contribution of gain or loss of function and the imbalance in the SphK/S1P rheostat to a plethora of pathological conditions including cancer, diabetes and inflammatory diseases. SphK is expressed as two isozymes SphK1 and SphK2, transcribed from genes located on different chromosomes and both isozymes catalyze the phosphorylation of sphingosine to S1P. Expression of each SphK isozyme produces alternately spliced isoforms. In recent years the importance of the contribution of SpK1 expression to treatment resistance in cancer has been highlighted and, additionally, differences in treatment outcome appear to also be dependent upon SphK isoform expression. This review focuses on an exciting emerging area of research involving SphKs functions, expression and subcellular localization, highlighting the complexity of targeting SphK in cancer and also comorbid diseases. This review also covers the SphK isoenzymes and isoforms from a historical perspective, from their first discovery in murine species and then in humans, their role(s) in normal cellular function and in disease processes, to advancement of SphK as an oncotarget.

\section{INTRODUCTION}

Sphingosine kinase (SphK), categorized as a bioactive lipid enzyme, is a central player in the sphingolipid rheostat [1-5]. The sphingolipid rheostat was first coined in the mid-nineties to describe the repression of ceramide-mediated programmed cell death through the conversion of sphingosine, a metabolite of ceramide, to sphingosine-1-phosphate (S1P) [5-7]. In this role, SphK modulates the balance between S1P, sphingosine and ceramides to maintain physiological levels of sphingosine and ceramide [8-10]. Activity of SphK/S1P is enhanced through cytokines, hormones, and growth factor stimulation [10-14]. Thus SphK is the rate-limiting enzyme that maintains the level of S1P for cell survival and normal cell proliferation and function. Conversely,
S1P is enzymatically degraded by S1P lyase to maintain the level of S1P at normal physiological levels (Figure 1) $[8,15]$. As will be described in this review, SphK has two major isoenzymes (isozymes), SphK1 and SphK2, and each isozyme is expressed as a number of isoforms [16-18]. Differences in conformation and dimerization properties, in addition to the varying subcellular localizations of SphK isozymes and isoforms, contribute to the diversity in SphK functions. SphK isozymes have some redundancy and compensatory functions in "normal" physiology, as described in mouse models. SphK knockout mice with deletion of either isozyme show no obvious phenotypic abnormalities [19-21]. Deletion of both isozymes results in embryonic fatality [19].

Recently our attention has been drawn to the diversity in biological functions of the SphK1 and SphK2 
isoforms whereby each isozyme has multiple isoforms differing only at the N-terminus [16, 22-24]. There is a strong suggestion that imbalances of SphK1 isoform abundance may play a crucial role in the pathophysiology of diverse diseases, may contribute to resistance to current anti-cancer drug therapies [25-27], and may have consequences for therapies targeting SphK1 and S1P in the presence of comorbid conditions $[15,28]$. Importantly, emerging evidence suggests that although high expression of both SphK-1a and -1b isoforms are associated with oncogenicity, the aberrant expression of the isoforms may be important to the efficacy of anti-SphK1 drug therapies $[25,26,28]$. Thus SphK isoform function and role in normal physiology and disease initiation and progression certainly merit further examination. This review updates our current knowledge of the SphK isozymes and highlights recent findings on the two prominent isoforms, SphK1a and SphK1b, and potential implications for efficacy of SphK1 directed cancer drug administration and outcome.

\section{CELLULAR PHYSIOLOGICAL ROLES OF SPHK, S1P AND S1P RECEPTORS (S1PR)}

The evolutionary conservation of SphK amino acid sequences from protozoa, zebrafish and mammals (illustrated in Supplementary Figure 1) and its ubiquitous presence in living tissues highlights the importance of the cellular signaling pathway mediated by $\mathrm{SphK}$ [10].
It is therefore undeniable that $\mathrm{SphK} / \mathrm{S} 1 \mathrm{P}$ signaling is indispensable for healthy cell maintenance [29]. One of the main functions across all species is the role of S1P as an intracellular second messenger regulating calcium mobilization, balancing cell growth and survival [10].

In mammals, SphK/S1P is pivotal for normal cellular physiology through roles in cell proliferation, survival, differentiation, motility and intracellular calcium regulation $[30,31]$. SphK activation of S1P is critical for embryonic development including, directed cell movement, organogenesis, cardiac development, maturation of vasculature, cellular immunity, and protection against apoptosis [10, 32]. S1P signaling is also essential for neurogenesis, lymphocyte trafficking and vascular development [33, 34]. Ongoing diverse roles for $\mathrm{SphK} / \mathrm{S} 1 \mathrm{P}$ in cellular maintenance also include protecting the heart and brain from ischemic damage [35, 36], protecting mitochondrial function [35, 37], regulating insulin synthesis, muscle insulin resistance, reduced glucose levels, maintenance of blood vessels and decreasing inflammation [15].

SphK promotes S1P activation through the dual intra- and extra- cellular actions of S1P, referred to as the "inside-out" signaling of S1P [38, 39]. Extracellular S1P acts as a primary messenger, or ligand receptor, whereby its signaling is modulated through binding to one of five-cell surface $\mathrm{S} 1 \mathrm{P}$ receptors $\left(\mathrm{S} 1 \mathrm{PR}_{1-5}\right)$, also referred to as $\mathrm{S} 1 \mathrm{P}$-specific $\mathrm{G}$ protein-coupled transmembrane receptors (GPCRs), and endothelial differentiation gene (EDG) receptors $[30,31,40,41]$. Regulation of S1P signaling through these five G-protein coupled-receptors is

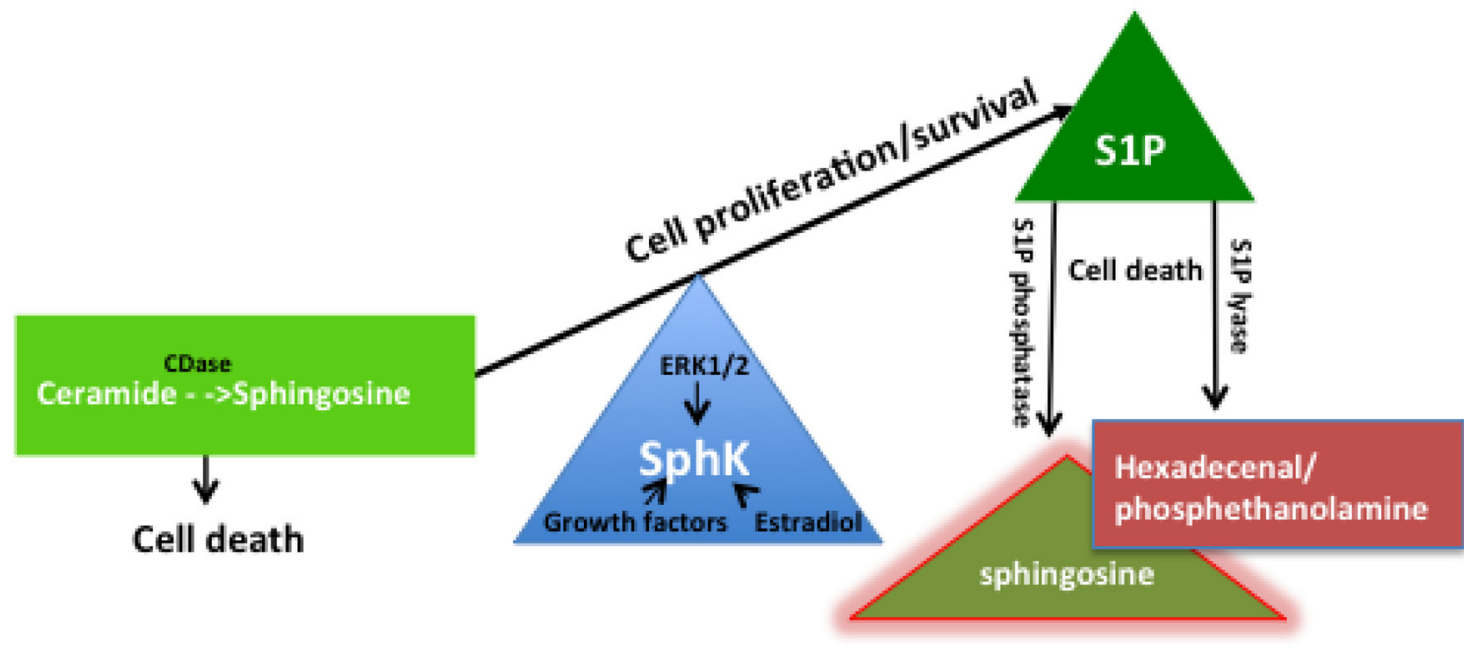

Figure 1: The sphingosine kinase (SphK) rheostat in the maintenance of cell proliferation and function. SphK is a phospholipid enzyme that converts sphingosine to S1P. Through the repression of sphingosine by phosphorylation, SphK modulates the balance between S1P and sphingosine and ceramides to promote cell survival, normal cell proliferation and cell function. SphK has intrinsic catalytic activity to facilitate a housekeeping role in maintaining physiological levels of sphingosine and ceramide and is also stimulated by mitogens such as growth factors, estradiol, and ERK. On the other hand, S1P lyase irreversibly degrades S1P into hexadecenal and phosphoethanolamine while S1P phosphatase dephosphorylates S1P to sphingosine to maintain physiological levels of S1P and maintain homeostasis. 
Table 1: Involvement of hSphK in the pathogenesis of cancer and other diseases

\begin{tabular}{|c|c|c|}
\hline Disease & Disease Sub-Type & Reference(s)* \\
\hline \multirow{11}{*}{ Cancer } & $\begin{array}{l}\text { Breast } \\
\text { Prostate }\end{array}$ & $\begin{array}{l}{[11,14,28,89-97]} \\
{[26,98-106]}\end{array}$ \\
\hline & Leukaemia & {$[107-111]$} \\
\hline & Lung & [112-116] \\
\hline & Pancreas & [117-120] \\
\hline & \begin{tabular}{|l|} 
Renal \\
\end{tabular} & [121] \\
\hline & Colon & {$[80,81,122]$} \\
\hline & Gastric & {$[123]$} \\
\hline & Liver and bile ducts & {$[124,125]$} \\
\hline & Ovarian and Cervical & [126-130] \\
\hline & Brain (Glioma) & [131-135] \\
\hline & Melanoma & [136-139] \\
\hline \multirow{4}{*}{ Neurodegenerative diseases } & Parkinson's disease & [140-143] \\
\hline & Alzheimer's disease & {$[142,144-154]$} \\
\hline & Amyotrophic lateral sclerosis (ALS) & {$[155]$} \\
\hline & Dementia & {$[156]$} \\
\hline \multicolumn{2}{|l|}{ Diabetes } & {$[76,157-175]$} \\
\hline Inflammatory diseases & $\begin{array}{l}\text { Asthma, Atherosclerosis, Inflammatory bowel } \\
\text { disease, Edema Autoimmune disorders such as } \\
\text { rheumatoid arthritis and multiple sclerosis }\end{array}$ & {$[176-196]$} \\
\hline \multicolumn{2}{|l|}{ Osteoporosis } & [197-201] \\
\hline \multicolumn{2}{|l|}{ Cardiovascular } & {$[163,202-205]$} \\
\hline \multicolumn{2}{|l|}{ Liver } & {$[161,205-213]$} \\
\hline \multicolumn{2}{|l|}{ Renal } & [214-218] \\
\hline
\end{tabular}

*This is not an exhaustive list of SphK references but includes the most relevant studies for each disease type.

important for normal development and vascular maturation $[31,41]$. This family of S1PRs are differentially regulated in different cell types to exert different cellular responses to $\mathrm{S} 1 \mathrm{P}$ activation. The $\mathrm{S}_{1} \mathrm{P}_{1-3}$ receptors are widely distributed whereas $\mathrm{S}_{1} \mathrm{PR}_{4}$ is expressed in lymphoid tissues and lung, and $\mathrm{S}_{1} \mathrm{PR}_{5}$ expression is restricted to the nervous tissue, each receptor having distinct, and overlapping intracellular signaling pathways [41]. Not all the S1PRs are expressed on cells at the same time, and may be differentially expressed depending on stage of maturation and activation of the cell [31]. In mouse models, $\mathrm{S}_{1} \mathrm{PR}_{1}$ is essential for embryonic vascular development [34], whereas $\mathrm{S}_{1} \mathrm{PR}_{2}$ and $\mathrm{S}_{1 \mathrm{PR}_{3}}$ show no obvious phenotypic differences [42]. In addition to extracellular S1P acting through S1PRs, S1P can function independently of S1PRs inside the cell as a second messenger. As reviewed by Strub and colleagues [43] the type of SphK isozyme and the location within the cell are responsible for the 'inside-out' signaling of S1P in response to extracellular stimuli.

In summary, the activation and response to S1P varies in a cell- or tissue- specific manner resulting from the SphK isozyme expression, sub-compartment localization of these enzymes, and the differential expression of the $\mathrm{S} 1 \mathrm{P}$ receptors. The importance of these specific interactions in cancer transformation will be discussed.

\section{SPHINGOSINE KINASE ISOENZYMES (ISOZYMES)}

Previous studies have identified two SphK isozymes, SphK1 (SK1, SPK1) and SphK2 (SK2, SPK2), each with the ability to catalyze the phosphorylation of sphingosine to its pro-active form S1P [16, 22-24]. Both SphKs isozymes act through the same substrate, sphingosine, and exert intra- and extracellular actions through their ability to phosphorylate sphingosine to S1P [10]. The two isozymes have different tissue distribution with SphK1 being highly expressed in spleen, lung and leukocytes and SphK2 being highly expressed in liver and kidney [16]. SphK2 also appears much later in embryologic development compared to SphK1 [16]. As shown in murine models, knockout of both SphK isozymes is lethal, leading to embryonic fatality and SphK deficient mice present with defects in neural and vascular development [19].

The two isozymes are expressed from different chromosome locations: the gene encoding the SphK1 isozyme is located on chromosome 17 (17q25.2) 
Table 2: SphK inhibitors

\begin{tabular}{|c|c|c|}
\hline SphK inhibitor & SphK selectivity & References \\
\hline SKi (2-(p-hydroxyanilino)- 4-(p-chlorophenyl)thiazole) or SK1-II & SphK1 and SphK2 & {$[18,47,239]$} \\
\hline Safingol & SphK1 and SphK2 & {$[283]$} \\
\hline L-threo-dihydrosphingosine (DHS) & SphK1 and SphK2 & {$[284]$} \\
\hline N,N-dimethyl-D-erythro-sphingosine (DMS) & SphK1 and SphK2 & {$[18]$} \\
\hline B-5354c, F-12509A (Natural products) & SphK1 and SphK2 & [18] \\
\hline ABC294735 & SphK1 and SphK2 & [47] \\
\hline Amgen 82 & SphK1 and SphK2 & [276] \\
\hline Amidine-based range of sphingosine analogues & SphK1 and SphK2 & {$[18]$} \\
\hline MP-A08 & SphK1 and SphK2 & [271] \\
\hline ST-1083 & SphK1 and SphK2 & [285] \\
\hline $\begin{array}{l}\text { S-15183a and S-15183b } \\
\text { (Natural product) }\end{array}$ & Not specified & [18] \\
\hline $\begin{array}{l}\text { PF-543 ((R)-(1-(4-((3-methyl-5-(phenylsulfonylmethyl)phenoxy) } \\
\text { methyl)benzyl)pyrrolidin-2-yl)methanol), SK1-5c (CAY10621), } \\
\text { SK1-178, VPC96091 (36a), CB5468139 }\end{array}$ & $\begin{array}{l}\text { SphK1 } \\
\text { SphK1 }\end{array}$ & $\begin{array}{l}{[111,286][287]} \\
{[239,288]} \\
{[239,288]}\end{array}$ \\
\hline SKI-I & SphK1 & {$[97,289,290]$} \\
\hline LCL351 & SphK1 & [291] \\
\hline Compound inhibitors 51 and 54 & SphK1 & {$[271,292]$} \\
\hline Balanocarpol & SphK1 & {$[293]$} \\
\hline VPC94075 & SphK1 & [294] \\
\hline $\begin{array}{l}\text { 1-deoxysphinganines } 55-21 \text { and } 77-7 \\
\text { (induces proteasomal degradation -SK1) }\end{array}$ & SphK1 & $\begin{array}{l}{[295]} \\
(55-21)\end{array}$ \\
\hline RB-005 & SphK1 & [296] \\
\hline (S)-FTY720 vinylphosphonate & SphK1 & [297] \\
\hline Genzyme & SphK1 & {$[27,276]$} \\
\hline $\mathrm{ABC} 294640$ & SphK2 & {$[18,298]$} \\
\hline SG-12 and SG14 (sphingosine analog) & SphK2 & [299] \\
\hline SLC5111312 and SLM6041434 & SphK2 & {$[300]$} \\
\hline F02 thiourea adduct of sphinganine & SphK2 & {$[295]$} \\
\hline VT-ME6 & SphK2 & {$[301]$} \\
\hline (2S,3S,4R)-Pachastrissamine & SphK2 & {$[302]$} \\
\hline Trans-12a and Trans $12 \mathrm{~b}$ & SphK2 & {$[301]$} \\
\hline SLR080811, SLP120701 & SphK2 & [239] \\
\hline K145 & SphK2 & {$[239]$} \\
\hline
\end{tabular}

Adapted from [303]

and the gene encoding the SphK2 isozyme maps to chromosome 19 (19q13.2) [16]. The SphK2a and SphK1a isozymes, differ considerably in size (618 amino acids in length compared to 384 amino acids respectively) but, nonetheless, retain $45 \%$ overall identity and $80 \%$ similarity with comparable enzymic activity [16]. Although the two SphK isozyme protein sequences differ, they share five conserved domains involved in ATP binding and catalytic conversion of sphingosine to S1P $[44,45]$. The size difference between the two isozymes result from additional amino acids in the N-terminal region, and a unique central proline-rich region which appears to coincide with the sphingosine binding region [46]. Studies of this SphK2 unique proline-rich region suggest it may confer some promiscuity to this isozyme in context of substrates it can phosphorylate [46]. This unique $\mathrm{N}$-terminal region also allows for the targeting of isozyme selective inhibitors. Differences in the sphingosine binding region between the two SphK isozymes also allow SphK1 and SphK2 selective ATP competitive inhibitors to be 
developed therefore permitting isozyme-specific inhibitory therapeutic targeting [47]. SphK2 also contains a nine amino acid domain similar to the pro-apoptotic $\mathrm{BH} 3$ domain ( $\mathrm{Bcl} 2$ homology domain 3), which is believed to be involved in the control of calcium levels in the cell, and in some culture conditions such as serum starvation [22].

Initial studies in SphK1 and SphK2 knockout mouse models describe opposing functions of overexpression of $\mathrm{mSphK} 2$ and $\mathrm{mSphK} 1$ isozymes, SphK1 is linked with pro-survival and cell maintenance functions, whereas SphK2, in contrast, has been linked with cell growth inhibition and enhanced cellular apoptosis [22]. Interestingly, this simplistic viewpoint has shifted [46] and recent emerging functions of SphK1 and SphK2, relevant to the newly emerging SphK-targeting cancer therapies, will be discussed. The different biological functions of the two SphK isozymes have been attributed to differing temporal and spatial regulation through post-translational modification and specific protein and lipid interactions [46], which allows for localized S1P production and provides downstream targets within the cell $[22,48]$. This distinct intracellular sub-compartmentalization has been cited as the driving force underpinning their diverse biochemical roles ( [48] and references therein). SphK1 is located mainly in the cytoplasm and the cell membrane whereas SphK2 is mainly located in the mitochondria, nucleus, and the endoplasmic reticulum (ER) (Figure 2) $[37,48-50]$. Overexpression of $\mathrm{SphK} 2$ increases cytosolic free calcium, inducing apoptosis, which is partly attributed to the unique SphK2-specific pro-apoptotic BH3 domain, not present in SphK1 [22]. Established functional roles for SphK1 in actin remodeling, endocytic recycling and endocytic membrane trafficking to maintain plasma membrane homeostasis have been described [51]. Furthermore, SphK1 has an important role in neurotransmission and is highly enriched in nerve
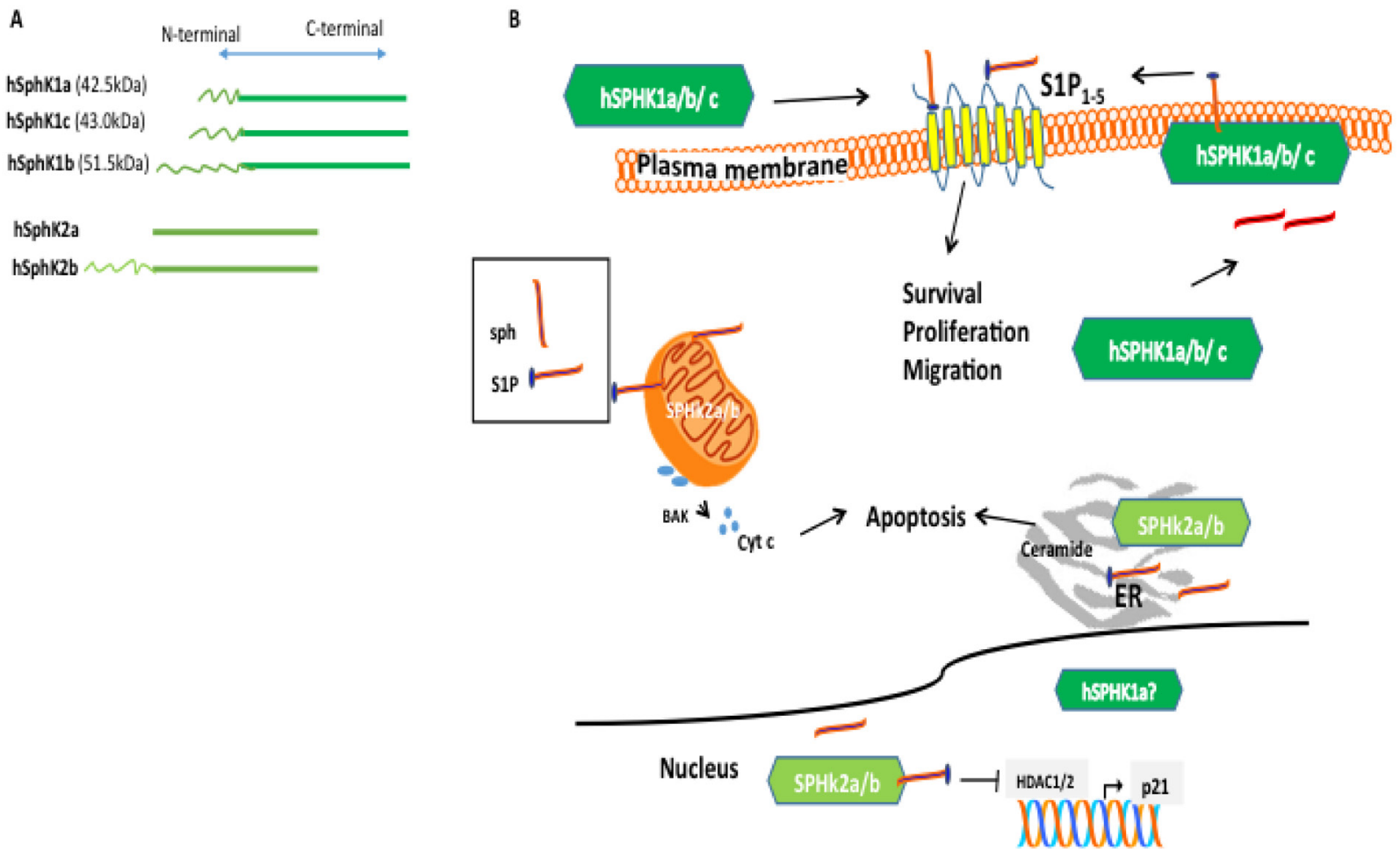

Figure 2: Subcellular distribution of SphK isozymes and function. A. SphK is expressed as two isozymes designated SphK1 and SphK2. Each SphK isozyme has variant isoforms differing only at the N-terminus. B. The distinct functions of hSphK1 and hSphK2 isozymes are believed to be associated with subcellular localization. SphK2 isoforms are predominantly localized in the nucleus, mitochondria, and endoplasmic reticulum (ER) and produce S1P. While located at the ER, SphK phosphorylates sphingosine to S1P, conversely, S1P phosphatase removes the phosphate and S1P lyase degrades S1P to induce apoptosis. In the mitochondria, Sphk2 catalysis to produce S1P triggers the apoptotic pathway by activating BAK and Cyt C. Conversely, hSphK1 is predominantly located in the cytoplasm and translocates to the membrane upon activation. Upon activation, hSphK1a/b/c phosphorylates sphingosine to produce S1P and has an "inside/outside" mechanism whereby S1P is translocated outside the cell and can bind to S1P ${ }_{1-5}$ receptors (also referred to as G-coupled receptors) contributing mainly to cell survival. HSphK1 isoforms have also been found extracellular. In mice, SphK1 isoform $\mathrm{b}$ has been shown to be located to the plasma membrane and more susceptible to degradation, however, to-date, no distinction between hSphK1 isoform localization has been demonstrated in the different human cells and human tissue with the exception that hSphK1a has been shown to be distributed in the nucleus and cytoplasm in cell culture. Fig 2B has been adapted from [27]. 
Table 3: Comparative selectively of the S1P modulators

\begin{tabular}{|c|c|c|}
\hline S1P modulator & S1PR selectivity & References \\
\hline \multicolumn{3}{|l|}{ Agonists } \\
\hline FTY720* & ${\mathrm{S} 1 \mathrm{P}_{1}}>\mathrm{S}_{1} \mathrm{P}_{5}>{\mathrm{S} 1 \mathrm{P}_{4}}>\mathrm{S} 1 \mathrm{P}_{3}$ & {$[110]$} \\
\hline $\begin{array}{l}\text { Fingolimod* and phosphorylated } \\
\text { fingolimod } \\
\text { (Trade name: Gilenya) }\end{array}$ & $\mathrm{S}_{\mathrm{PPR}}, \mathrm{S}_{1} \mathrm{PR}_{3}, \mathrm{~S}_{1} \mathrm{PR}_{4}, \mathrm{~S}_{1} \mathrm{PR}_{5}$ & {$[234,304-308]$} \\
\hline S1P-specific antibody & Depletion of S1P & {$[18]$} \\
\hline CS-0777* & ${\mathrm{S} 1 \mathrm{P}_{1}}_{1}>{\mathrm{S} 1 \mathrm{P}_{5}}_{5}>{\mathrm{S} 1 \mathrm{P}_{3}}$ & {$[309]$} \\
\hline Ponesimod (ACT-128800) & ${\mathrm{S} 1 \mathrm{P}_{1}}_{1}>{\mathrm{S} 1 \mathrm{P}_{5}}_{5}>{\mathrm{S} 1 \mathrm{P}_{3}}$ & {$[271]$} \\
\hline RPC0163* & 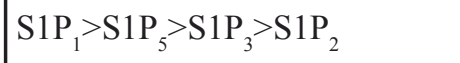 & {$[271]$} \\
\hline ONO-4641 & $\mathrm{S}_{1} \mathrm{P}_{1}>\mathrm{S}_{1} \mathrm{P}_{5}>\mathrm{S} \mathrm{P}_{4}$ & {$[310,311]$} \\
\hline Siponimod (BAF312) & $\mathrm{S}_{1} \mathrm{P}_{1}>\mathrm{S} \mathrm{P}_{5}>\mathrm{S} \mathrm{P}_{4}$ & {$[312]$} \\
\hline GSK2018682 & ${\mathrm{S} 1 \mathrm{P}_{1}}_{1}>{\mathrm{S} 1 \mathrm{P}_{5}}_{5}$ & {$[271]$} \\
\hline SEW2871 & $\mathrm{S}_{1} \mathrm{P}_{1}$ & {$[313,314]$} \\
\hline AUY954 & $\mathrm{S}_{1} \mathrm{P}_{1}$ & {$[315,316]$} \\
\hline MT-1303 & $\mathrm{S}_{1} \mathrm{P}_{1}$ & {$[271]$} \\
\hline KRP-203 and phosphorylated KRP-203 & ${\mathrm{S} 1 \mathrm{P}_{1}}_{1}>\mathrm{S}_{1} \mathrm{P}_{4}$ & {$[317,318]$} \\
\hline $\begin{array}{l}\text { AAL(R) and phosphorylated AAL(R) } \\
\text { (FTY720 analogue) }\end{array}$ & S1PR1, S1PR3, S1PR4, S1PR5 & {$[294,319,320]$} \\
\hline CYM-5442 & $\mathrm{S}_{1} \mathrm{P}_{1}$ & {$[321,322]$} \\
\hline VPC23153 & $\mathrm{S}_{1} \mathrm{P}_{4}$ & {$[323,324]$} \\
\hline W-061 & $\mathrm{S}_{1} \mathrm{P}_{1}>\mathrm{S}_{1} \mathrm{P}_{5}>\mathrm{S}_{1} \mathrm{P}_{4}>\mathrm{S}_{1} \mathrm{P}_{3}$ & {$[310,325]$} \\
\hline CYM-5442 & $\mathrm{S}_{\mathrm{P}} \mathrm{P}_{1}$ & {$[321,322]$} \\
\hline CYM-5478* & $\mathrm{S}_{1} \mathrm{P}_{2}$ & {$[326]$} \\
\hline \multicolumn{3}{|l|}{ Antagonists } \\
\hline $\begin{array}{l}\text { VPC44116 } \\
\text { VPC23019 } \\
\text { VPC25239 }\end{array}$ & $\mathrm{S}_{1} \mathrm{P}_{1}$ and/or $\mathrm{S}_{1} \mathrm{P}_{3}$ & {$\left[\begin{array}{l}{[18]} \\
{[327]}\end{array}\right]$} \\
\hline TASP0277308 & $\mathrm{S}_{\mathrm{P}} \mathrm{P}_{1}$ & {$[328]$} \\
\hline W146 & ${\mathrm{S} 1 \mathrm{P}_{1}}_{1}$ & \begin{tabular}{|l|}
$329,330]$ \\
\end{tabular} \\
\hline JTE-013 & $\mathrm{S}_{1} \mathrm{P}_{2}$ & {$[189,331]$} \\
\hline NIBR-0213 & ${\mathrm{S} 1 \mathrm{P}_{1}}_{1}$ & {$[329]$} \\
\hline
\end{tabular}

Note: *S1P modulators can act as functional antagonists.

More detailed reviews [15, 18, 56, 57, 332].

terminals, specialized subcellular compartments of exoendocytosis [51].

Interestingly, despite the distinct properties and locations of SphK1 and SphK2 within the cell and mice with deletion of both isozymes is embryologically lethal, mice with deletion of either isozyme show no obvious 
abnormalities at birth, remain viable, have no obvious differences in longevity, and histological analysis reveals no major abnormalities of organ structure, [19, 52], and SphK1 knockout mice exhibit normal inflammatory response [20, 53], suggesting that there is some redundancy in SphK1 and SphK2 functions in "normal" physiology, and also indicates compensatory functions for both isozymes in the cell. This "compensatory" mechanism, whereby SphK1 and SphK2 complement each other's actions may be explained, in part, by the potential fluidity of the two isozymes allowing the SphKs isozymes to move between subcellular compartments [54, 55]. The proposed concept suggests that this partitioning of the isozymes into lipid microenvironments would allow SphK-isozyme specific catalytic conversion of sphingosine to S1P and effective binding to localized S1P receptors otherwise not normally accessible if under strict subcellular compartmentalization. Despite the importance of SphK in normal cellular function and the strong association between aberrant SphK/S1P signaling and diseases, the mechanisms whereby lipid kinases locate and act on their substrates, in general, is not well understood.

\section{INVOLVEMENT OF SPHK AND S1P IN THE PATHOGENESIS OF CANCER AND OTHER DISEASES}

As key players in normal physiology and in disease, it is unsurprising that there is a large body of evidence demonstrating the contribution of an imbalance in the SphK/S1P rheostat to a plethora of pathological conditions including cancer, diabetes, inflammatory diseases, neurodegenerative diseases (Parkinson's and Alzheimer's), cardiovascular and liver diseases, which have been extensively reviewed $[2,3,11,15,18,48,56-$ 72]. Although removal of one of the major SphK isozymes is not fatal, as determined in mice with knockout of either SphK1 or SphK2, what these studies have revealed is that loss of one isozyme increases the risk of major health problems including altered vasculature formation [73, 74], impairment in wound healing [75], abnormal islet formation, which could lead to type 1 diabetes [76], and cardiac dysfunction (ischemic) [77], among other complications. Alternatively, overexpression of SphK1 and aberrations in the "inside-out" dual mechanism of SphK1/S1P activation have been reported as contributors to cancer and inflammation [38, 39, 56, 78, 79], and this is supported by studies in SphK1-deficient mice,

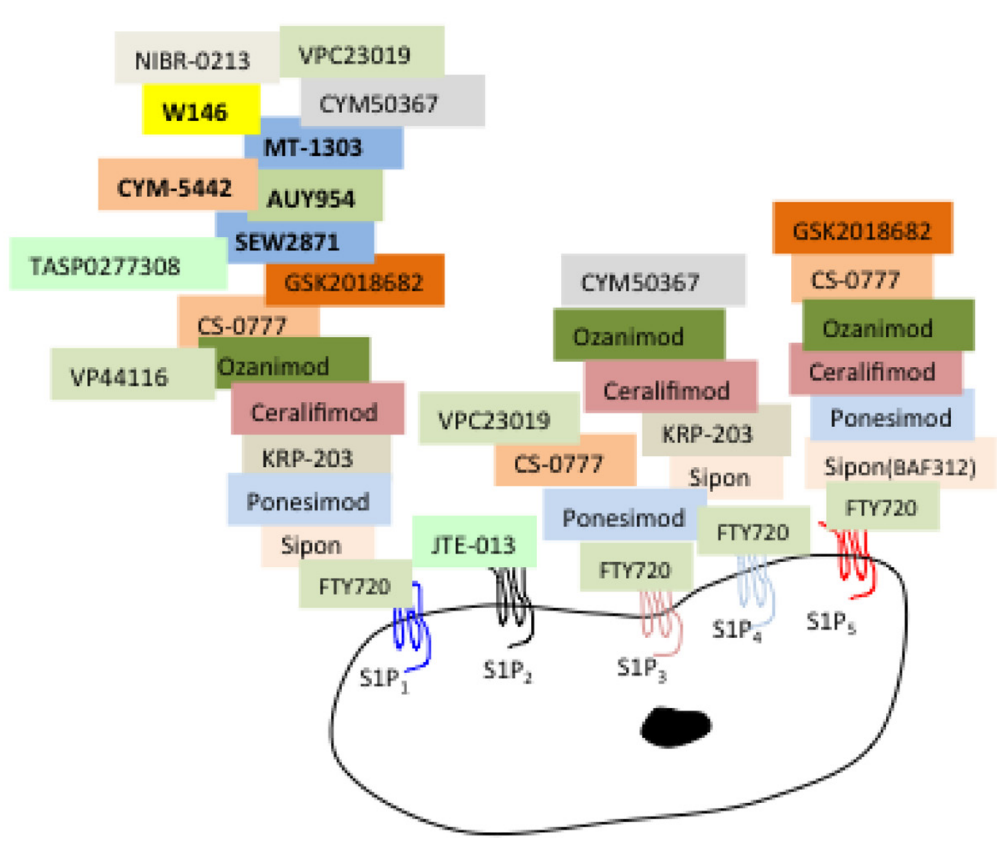

Figure 3: Designer anti-S1PR1-5 drug specificity. Update of $1^{\text {st }}$ and $2^{\text {nd }}$ generation S1P receptor modulators developed to target individual and multiple S1P receptors. Each of the receptor modulators binds to individual or multiple receptors to block or activate the SIPRs as illustrated. MOST S1PR modulators target 2 or more receptors. Sipon (BAF312) - Siponimod is a S1P1 = 5 $>4$ modulator; Ponesimod (ACT-128800) is an agonist for S1P1 $>5>3$; KRP-203 is an agonist for S1P1 $>4$; Ceralifimod (ONO-4641) is an agonist for $\mathrm{S} 1 \mathrm{P} 1=5>4$; Ozanimod (RPC1063) is an agonist for S1P1 $>5>4$; Cs-0777 is an agonist for S1P1 $>5>3$; GSK2018682 is an agonist for S1P1 > 5. JTE-013 is a competitive antagonist specifically for S1P2. CYM50367 targets S1PR1/4 and VPC23019 targets S1PR1/3. Sew2871, AUY954, MT-1303, CYM-5442, W146, NIBR-0213, TAS0277308, are listed as selective S1P1 modulators. These novel S1P receptors and downstream signaling pathways and functions are reviewed in [15, 258, 281]. 
for example, reduction of SphK1 reduced colon cancer development $[80,81]$.

Although initial studies focused on SphK2 as a pro-apoptotic protein more recent evidence describes dual functionality for SphK2: a protective function in cell maintenance as well as its characterized pro-apoptotic functions. As reported by Gaire [82], SphK2 is protective against neuronal ischemic injury, potentially protecting the junctional protein in the blood-brain barrier $[36,83-$ 86]. Furthermore, S1P production by SphK2 potentially protects dopaminergic neurons, the major source of dopamine, and potentially provides some protection against Parkinson's disease through maintaining and promoting mitochondrial function [70]. Massberg and colleagues provide evidence demonstrating SphK2 expression, regulates platelet aggregation and that deletion of SphK2 leads to reduced arterial thrombosis after vascular injury, suggesting SphK2 is a potentially important target for protection against arterial thrombosis $[73,74]$. Knockout SphK2 mouse models also revealed the importance of SphK2 in cardio protection and survival of the heart $[87,88]$.

This review is not intended to cover, in any depth, the ever-growing list of disorders and/or the substantial evidence presented for the involvement of SphK/S1P in health and disease. For this information we refer the readers to the cited references and the seminal papers listed in Table 1. However, the changes that occur in the SphK/ S1P signaling pathways in normal compared to abnormal cells is still being unraveled and the involvement of SphK isozymes, isoforms, S1P and S1PR in the pathophysiology of cancer will be covered in more depth.

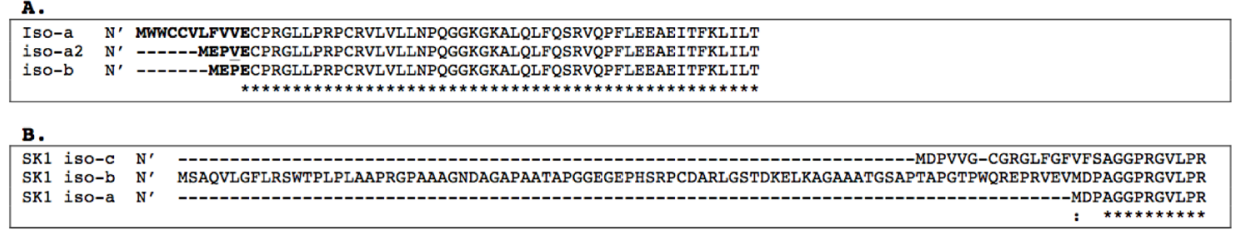

Figure 4: Alignment of the N-terminal amino acid sequences of the mSphK1 and hSphK1 isoforms. A. Three mSphK1 isoforms (iso-a, iso-a2, and iso-b) have been identified to date. Iso-a has an additional 6 and 7 amino acids at the N-terminus (N') compared to the mSphK1 12 and $\mathrm{mSphK} 1 \mathrm{~b}$ isoforms respectively. There is 10 amino acid overall sequence dissimilarity when comparing mSphK1a to mSphK1a2 and mSphK1b. MSphK1a2 differs from mSphK1b by an insertion of a valine (V) in the N' changing the sequence MEPVE (iso-2a) to MEPEE (iso-b). B. Human SphK1 is expressed as 3 isoforms ( $a, b$, and c) which have identical in sequences except for the N-terminus (N'). The SphK1b N' has an additional 86 amino acids upstream of the Met start codon of SphK1a, as illustrated. SphK1c has an additional 14 amino acids upstream from the SphK1a start codon, which translates to a difference of 17 amino acids between the SphK1a isoform compared to SphK1c. Legend: * = complete amino acid sequence identity across all isoforms; : = similarity of amino acids across 2 isoforms. Sequences aligned using CLUSTAL Omega (1.2.3) multiple sequence alignment tool.

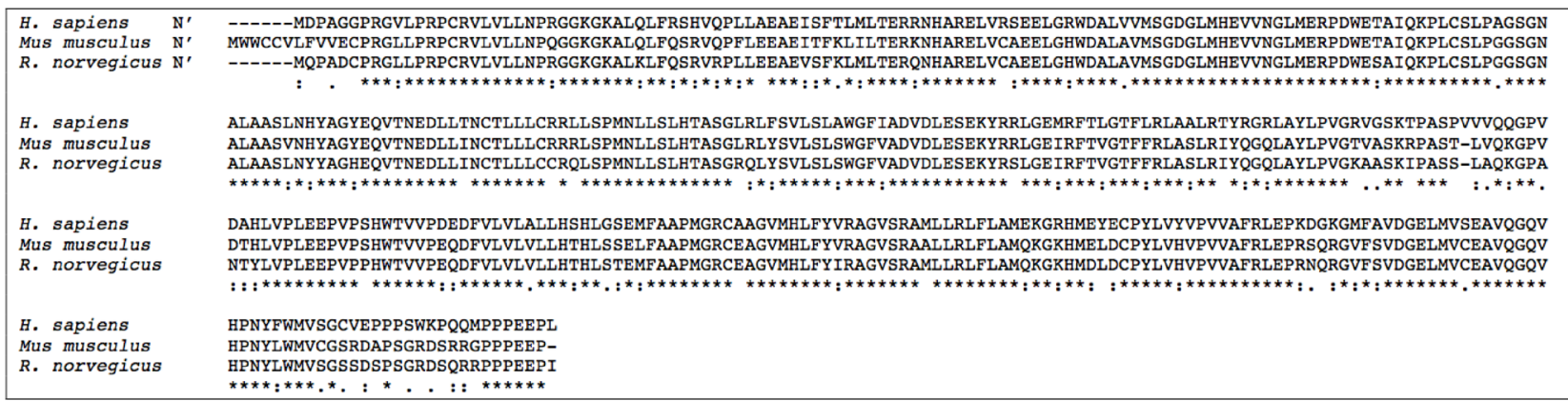

Figure 5: Comparative alignment of human and murine SphK1 amino acid sequences. SphK1 amino acid sequence alignment showing similarities and differences in SphK1 sequences across human (H. sapiens), mouse (Mus musculus) and rat (R. norvegicus) species. Legend: * = complete amino acid sequence identity across all three species; : = similarity of amino acids across 2 species. Sequences aligned using CLUSTAL Omega (1.2.3) multiple sequence alignment tool. 
INTRACELLULAR

AND

EXTRACELLULAR TARGETS OF S1P

REGULATED BY SPHK1 AND SPHK2 AND

RELEVANCE TO CANCER

\section{Validation of SphK1 and SphK2 as targets for anti-cancer treatment}

Disruption of the sphingolipid rheostat has been well reported as a determinant of initiation and progression of many cancers (Table 1) and a focus for anti-cancer treatments. Removal of SphK tips the balance from production of the pro-active lipid S1P, which is involved in cell proliferation, to the production of the inactive or less active ceramide lipid with pro-apoptotic functions (Figure 1). Extensive studies from mouse models and cancer cell lines have placed SphK1 as a target for cancer therapy. Studies using genetic knockdown of SphK1 and $\mathrm{SphK} 2$ in mouse colon cancer models revealed SphK1 $1^{--}$ mice were significantly protected against colon cancer whereas this protection was not evident in SphK2 $2^{-/}$mouse models [80]. Knockdown of SphK1 using siRNA in glioma and breast cancer cell models decreases S1P levels with an accompanying accumulation of ceramide resulting in increased apoptosis [134, 219]. Based on these initial findings SphK1 was identified as a prospective oncogenic target. Interestingly, hSphK2 ablation using RNA interference technology was shown to be more efficacious in inducing cell death $[134,220]$ validating both SphK1 and SphK2 as targets for anti-cancer treatment. Here we present an overview of hSphK1 and hSphK2 isozymes and an alternative perception of $\mathrm{hSphK} 2$ as a more efficient target for anti-cancer therapy compared to SphK1.

\section{Oncogenic properties or "non-oncogenic addiction" of SphK1/S1P}

Overexpression of SphK1 has been reported as a driver for many types of cancer and contributes to chemotherapy resistance and poor patient outcome (Table 1 and references therein). Xia and colleagues first identified the oncogenic potential of SphK1 in 2000 [221], and evidence supporting a key role in neoplastic survival and growth has come from SphK1 $1^{-/}$mouse models showing reduced tumor size [222] and increased expression of hSphK1 has been reported in many different cancer types (Table 1) [97, 223]. Although SphK1 is now categorized as an oncogene, there is no evidence associating carcinogenesis with the presence of genetic mutations of SphK1 [224]. It has been widely suggested that the oncogenic properties of SphK1 are associated with "gain of function" through the overexpression and hyper-activation of S1P mediated intra- and extracellular signaling, or "non-oncogenic" addiction, may be responsible for SphK-associated pathophysiology [225]. Non-oncogenic addiction refers to the over reliance of cancer cells on the SphK1 signaling pathway for survival [226]. Normal cells do not usually tolerate high levels of SphK1 and in some cases high SphK1 in normal cells has been reported to have an anti-proliferative effect [225]. Enhanced intra-cellular signaling through SphK1/ $\mathrm{S} 1 \mathrm{P}$, independent of G-coupled receptors, was proposed

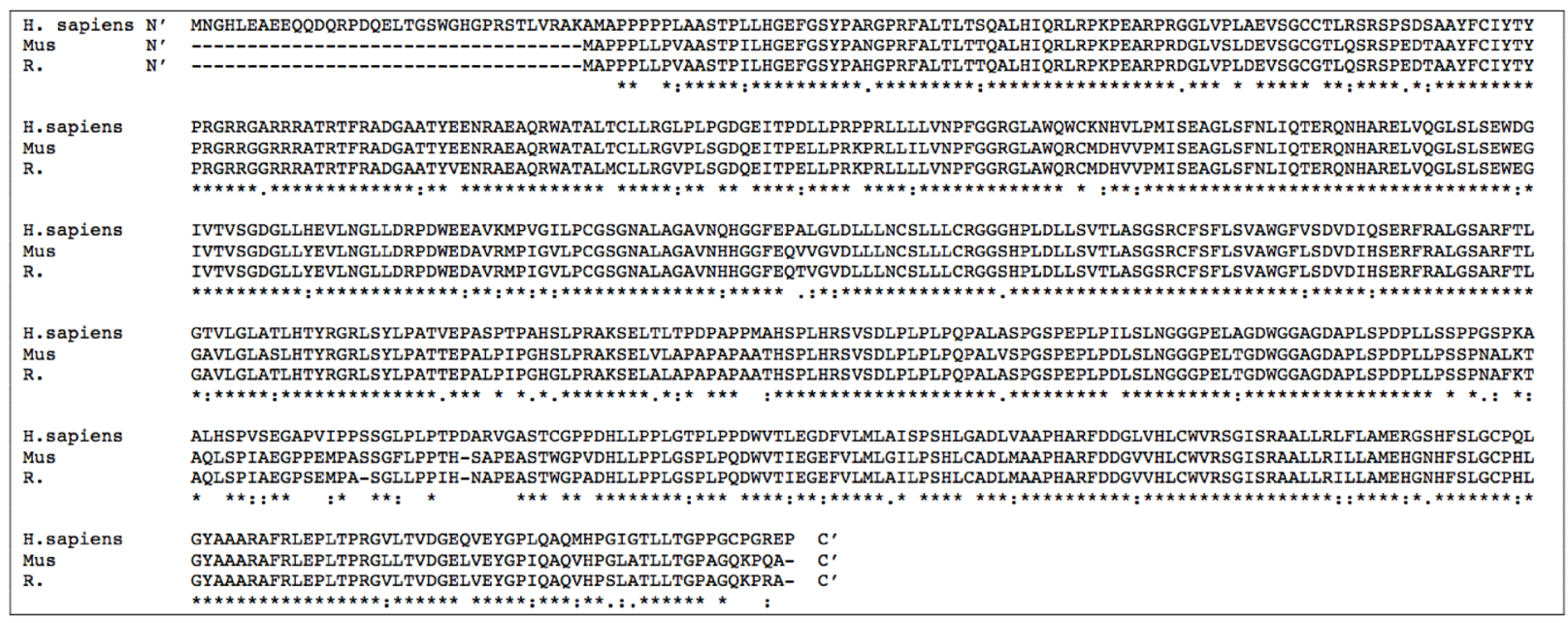

Figure 6: Comparative alignment of human and murine SphK2 amino acid sequences. SphK2 sequences have been aligned to show similarities and differences between the SphK2 isozyme sequences across human (H. sapiens), mouse (Mus musculus) and rat (R. norvegicus) species. Legend: $*=$ complete amino acid sequence identity across all three species, $:=$ similarity of amino acids across 2 species. Sequences aligned using CLUSTAL Omega (1.2.3) multiple sequence alignment tool. 
as a mechanism responsible for hyper-proliferation and cell survival [227, 228]. However, increases in SphK1 and increases in SphK1 signaling mediated both intra and extra-cellular through a plethora of different molecules have been identified as participating in the "gain of function" leading to tumorigenesis and have been extensively reviewed in [18]. For example "gain of function" may occur through S1P stimulation of SphK1 mediated by agonists such as, growth factors, estradiol, insulin, cytokines and/or extracellular signaling kinases (ERK) [90, 91, 225, 229]. Estrogen stimulates SphK1 to promote breast cancer development [91, 93] and is also associated with breast cancer treatment resistance [230]. SphK1 mediates insulin-like growth factor binding protein-3 (IGFBP-3) growth factor signaling in breast cells, where overexpression of IGFBP-3 is associated with cancer progression [14]. Proinflammatory cytokines, immunoglobulin receptors, small GTPases, calcium and protein kinase activators, are all described as mediators of SphK1/S1P activity [18, 135]. For example, interleukin 1 (IL-1) stimulates SphK1 (not SphK2) in the brain contributing to chronic neuroinflammation and stimulation of malignant glial cells correlating with poor prognosis for patients with glioblastoma multiforme [135].

Although the overexpression of SphK1/S1P appears to be associated with promoting malignancy, it is becoming ever more evident that non-oncogenic addiction is also associated with aberrant localization and translocation of SphK1 post stimulation $[231,232]$. SphK1 is located mainly in the cytosol in unstimulated cells and upon stimulation by agonists SphK1 is upregulated and translocates to the plasma membrane. For example, SphK1 localized in the cytoplasm has been demonstrated to interact with the tumor necrosis factor-(TNF) receptor associated factor 2 (TRAF2), enhancing S1P activity associated with pro-survival cell signaling of S1P [233, 234], although it is noted that the TNF-mediated response appears to be cell-type and cell context specific [235, 236]. It was in 2005 that Pitson and colleagues proposed that intra-cellular dysregulation of SphK1 phosphorylation and localization, rather than total increase in SphK1 levels, were key elements in the transformation of the malignant phenotype: i.e. subcellular-compartmentalization and translocation of SphK1 dictates cancer transformation [237]. All hSphK1 isoforms harbor a distinct phosphorylation site at Ser225, and phosphorylation of the SphK1-Ser225 site is important for translocation of SphK1 to the plasma membrane [55, 237]. Increased Ser225 phosphorylation of SphK1, as a direct consequence of extracellular ERK1/2-mediated phosphorylation at Ser225, was shown to enhance translocation of intracellular SphK1 to the membrane. As a consequence SphK1 demonstrated an increase in catalytic activity and bioactive S1P, proposing that the pro-cancer effect, or SphK1-oncogenic 'inside-outside' signalling, was reliant on both Ser225-specific phosphorylation and translocation to the membrane [237]. SphK1/S1P extracellular activity has also been shown to promote oncogenicity through initiation of the formation of new vasculature to support new tumor growth. Blocking SphK1/S1P inhibited the formation of new vasculature and hence deprived the tumor of important nutrients [19, 97, 238].

New insights into the structure and function of SphK1 relating to its enzymic role in controlling fundamental cellular processes has been recently reviewed by Adam, Pyne and Pyne [48]. Although the crystal structure of SphK1 is not yet available, comparative analysis of closely related prokaryotic lipid kinase crystal structures identified a potential dimerization region in SphK1, which would confer structural plasticity, or conformational mobility, through phosphorylation and interaction with other proteins and phospholipids. Physiology of enzymatic regulation may well be dependent on the structural plasticity of SphK1 and interactors and dysregulation of these interactions may contribute to disease. There is still a long way to go to understanding the structure and function of SphK1, and knowledge of the SphK1 crystal structure will allow the discovery of druggable allosteric sites and development of specific ligands to modulate SphK1 activity [48].

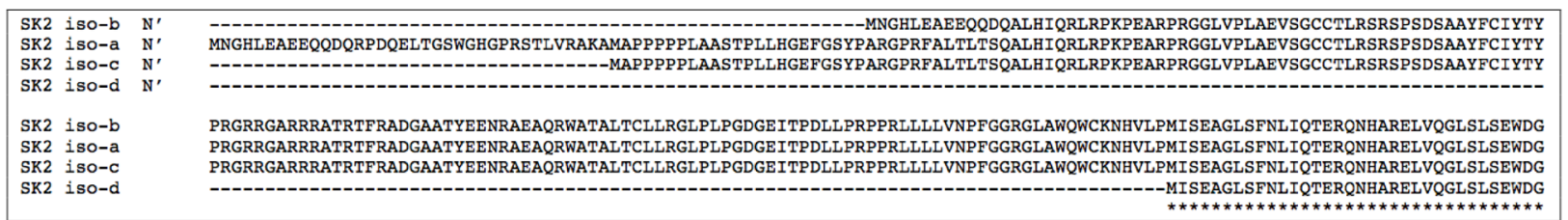

Figure 7: Predicted N-terminal sequence alignment of the hSphK2 isoforms. hSphK2 has 5 predicted isoforms differing only at the N-terminus as shown (iso-a, iso-b, iso-c and iso-d). The SphK2c isoform has a predicted 59 amino acid insertion in the N-terminal region compared to SphK2b. SphK2c has a predicted Met start site that is 36 amino acids downstream of the SphK2a (iso-a) start codon. SphK2d has the shortest sequence with a truncation of 86 amino acids from the SphK2a start codon. Legend: * = complete amino acid sequence identity across all isoforms. Sequences aligned using CLUSTAL Omega (1.2.3) multiple sequence alignment tool. 


\section{A role for $\mathrm{SphK2/S1P}$ in oncogenesis}

Albeit historically SphK1 is the isozyme associated with oncogenesis, it is important to note that there is new evidence to strongly suggest that SphK2 is overexpressed in many human cancers [239] and dual pro- and antiapoptotic functions of SphK2 may well be dictated by the cellular milieu within which the protein exists. Pitson and colleagues demonstrated that a relatively low increase in SphK2 levels (2.5 fold), compared to the levels in corresponding normal tissue, could potentially promote cell proliferation and neoplastic transformation, whereby in contrast, high levels of SphK2 are associated with pro-apoptotic signalling, predicted to be through the unique $\mathrm{BH} 3$ pro-apoptotic domain, that dominates over the proliferative SphK2/S1P response [239]. On the other hand, Xia and colleagues showed that insulin stimulated phosphorylation of SphK2 in a similar time- and dosedependent manner compared to SphK1, led to similar activation of cell cycle progression and proliferation in MCF- 7 cells [229].

The SphK2 isozyme contains nuclear import and export sequences, allowing shuttling between the nucleus and cytoplasm [240]. In the nucleus SphK2 complexes with histone $\mathrm{H} 3$ and histone deacetylase 1 and 2 (HDAC $1 / 2$ ) producing S1P that regulates histone acetylation, as part of gene regulation [241]. SphK2-derived S1P also binds hTERT to allosterically mimic phosphorylation and maintain telomere integrity and stability through limiting proteasome degradation [242]. As telomere stabilization is enhanced in cancer S1P stabilization of telomeres potentially enhances tumor growth, however this is somewhat controversial to its role in apoptosis or cell protection against cancer [243]. In addition, FTY720, a competitive inhibitor of SphK2, has been shown to inhibit DNA synthesis and as a consequence, inhibited S1Pstimulated actin rearrangement and reorganized the focal adhesion assembly in MCF-7 cells, potentially regulating the transition of MCF-7 cells from a stationary phenotype to a migratory phenotype [244].

Another example of SphK2 isozyme location influencing S1P function comes from Strub and colleagues who demonstrated S1P, produced by SphK2 in the mitochondria, specifically interacted with prohibitin 2 to control mitochondria respiration [37]. As genetic alteration and aberrant metabolism are two of the hallmarks of cancer, the link between overexpression of SphK2/S1P in the nucleus, affecting genetic gene regulation and stability, and SphK2/S1P altering mitochondria metabolism, may have consequences for cancer progression.

In other studies using RNA interference to selectively ablate each of the SphK isozymes, SphK1 ablation showed no effect on mRNA and protein levels of SphK2 however reduced intracellular S1P levels and increased ceramide (pro-apoptotic lipid), alternatively, SphK2 ablation increased intracellular activity of SphK1/
S1P [220]. Anti-intuitively, despite increased S1P levels in these experiments, reduction of SphK2 suppressed proliferation and migratory potential of cells more effectively than SphK1 ablation indicating targeting SphK2 may have stronger anti-cancer effects in cancer therapy [220].

As mentioned previously, there are inherent differences in the composition of the ATP and catalytic binding pockets of the two SphK isozymes, and specific SphK1 and SphK2 compounds have been developed targeting this peptide region to inhibit the catalytic activity of either isozyme and these are listed and referenced in Table 2. SphK2 specific inhibitors, such as the immunosuppressant drug ABC294640 and FTY720 have been shown to have greater or similar anticancer effects than compounds that target SphK1, such as CB5468139, or that target both isozymes, SK-II and ABC294735, making SphK2 inhibitors attractive compounds for anticancer therapy [47]. The drug $\mathrm{ABC} 294640$ has been shown to reduce the growth of hormone resistant prostate cancer cells [245] and colorectal and colon cancer cell growth [246, 247]. Though SphK1 does phosphorylate FTY720, which acts as a pseudo ligand for S1P, binding of SphK2 is more potent having a 30 -fold more ligandbinding efficiency in humans and murine species [248]. The effect of FTY720 binding to SphK2 in the nucleus and preventing HDAC $1 / 2$ repressor gene regulation has also been shown to restore ER $\alpha$ expression and hence restore tamoxifen sensitivity [249].

SphK2 also plays a role in cell migration in a cell specific manner. In the breast cancer cell line MDA-MB-453, cell migration towards the epidermal growth factor (EGF) was observed and this migration was abrogated by SphK2-specific siRNA whereas downregulation of SphK2 in HEK293 had no effect on migration [250]. Although it is not understood why SphK2 involvement in cell migration is cell specific, especially as the majority of endogenous SphK2 was present in the plasma membranes of both HEK293 and MDA-MB-253 cell lines and EGF did not affect obvious localization changes in SphK2, it may still be possible that SphK2 may relocate to specialized plasma membrane compartments and produce S1P in the vicinity of its receptors. Also there is some in vitro data to suggest that SphK2 can compromise the integrity of the endothelial cell monolayer [251], which may contribute to invasion and migration of cancer cells. The complex interaction between SphK and S1PR with reference to the potential role of SphK2 in regulating metastasis is discussed in more detail in the following section.

As there is indisputable evidence to support SphK2 compensatory mechanisms in the absence of SphK1 in 'normal' physiology (at least in mouse models) [19], and the discovery of SphK2 specific inhibitors (FTY720 and ABC294640), acting as competitive inhibitors of SphK2 (not SphK1), with the ability to be phosphorylated by 
Table 4: SphK/S1p/S1PR drugs in clinical trial

\begin{tabular}{|l|l|l|l|l|}
\hline Drug & SphK selectivity & Indications & $\begin{array}{l}\text { ClinicalTrials.gov } \\
\text { identifier }\end{array}$ & Phase \\
\hline Safingol & $\begin{array}{l}\text { Sphingosine } \\
\text { derivative, } \\
\text { PKC inhibitor }\end{array}$ & $\begin{array}{l}\text { Solid tumors, combined with } \\
\text { fenretinide } \\
\text { Solid tumors, combined with } \\
\text { cisplatin }\end{array}$ & $\begin{array}{l}\text { NCT01553071 } \\
\text { NCT00084812 }\end{array}$ & $\begin{array}{l}\text { I [283] } \\
\text { I Completed) }\end{array}$ \\
\hline ABC294640 & SPHK2 inhibitor & $\begin{array}{l}\text { Pancreatic cancer } \\
\text { Diffuse Large B Cell } \\
\text { Lymphoma } \\
\text { Multiple Myeloma } \\
\text { Carcinoma, Hepatocellular }\end{array}$ & $\begin{array}{l}\text { NCT01488513 } \\
\text { NCT02229981 } \\
\text { NCT02757326 }\end{array}$ & $\begin{array}{l}\text { I } \\
\text { I Not yet recruiting. } \\
\text { Not Yet recruiting. }\end{array}$ \\
\hline $\begin{array}{l}\text { Sonepcizumab } \\
\text { (ASONEP) }\end{array}$ & $\begin{array}{l}\text { S1P-specific } \\
\text { monoclonal } \\
\text { antibody }\end{array}$ & $\begin{array}{l}\text { Solid tumors } \\
\text { Unresectable and Refractory } \\
\text { Renal Cell Carcinoma }\end{array}$ & $\begin{array}{l}\text { NCT00661414 } \\
\text { NCT01762033 }\end{array}$ & $\begin{array}{l}\text { I (Completed) } \\
\text { II (Terminated) }\end{array}$ \\
\hline
\end{tabular}

Adapted from [78]

SphK2 and be released from cells to act on S1P receptors, also suggests a wider functionality for this isozyme and its role in neoplasia and cancer $[252,253]$.

The growing evidence supporting a role for SphK2 in cancer development provides sufficient precedent to warrant the inclusion of SphK2 as a candidate therapeutic target for many types of cancer.

\section{S1PR EXPRESSION AND MALIGNANCY}

There is ample evidence in the literature to suggest that the differential and overexpression of $\mathrm{S}_{1} \mathrm{PR}_{1-5}$ are involved in cancer progression and metastasis $[123,139$, 250, 254-256]. Differential expression of the S1PRs is known to occur at different stages of development, S1PR expression has been shown to be essential for embryonic development and normal physiological functions, especially in vascular maturation $[34,257]$, whereas $\mathrm{S} 1 \mathrm{PR}_{2}$ and $\mathrm{S} 1 \mathrm{PR}_{3}$ were reported to be redundant in this process [42]. In estrogen receptor positive (ER+) tumors high $\mathrm{S}_{1} \mathrm{PR}_{1}$ and $\mathrm{S}_{1} \mathrm{PR}_{3}$ were reported to be causally associated with tamoxifen resistance and poor prognosis [92], and in vitro, in ER+ MCF-7 breast cancer cells, the SphK1/S1PR 3 loop promoted breast cancer progression and migration [94]. S1PR/S1P has been shown to be important for osteoclast formation, bone cells that break down bone tissue. A few recent studies have demonstrated that FTY720 binding to $\mathrm{S}_{1} \mathrm{PR}_{1}$ and or S1PR 2 prevents osteoclast formation $[258,259]$. By blocking osteoclast formation and reducing bone loss, FTY720 may indirectly have added benefits for advanced cancers that migrate to the bone and where metastasis involves considerable osteolysis [260].

Interesting, in many cancer cells a shift in S1PR expression is observed whereby, $\mathrm{S}_{1} \mathrm{PR}_{1}$ expression is lost or decreased and $\mathrm{S} 1 \mathrm{PR}_{2}$ and/or $\mathrm{S}_{\mathrm{PPR}}$ are predominantly expressed [123, 139, 254, 255]. Moreover, within cancer cell sub-types, differences in S1PR expression correlate with the metastatic or non-metastatic cancer phenotype
[123, 139]. Yamashita and colleagues demonstrated that gastric cells expressing high levels of $\mathrm{S}_{1} \mathrm{PR}_{3}$ and low levels of S1PR 2 were causally correlated with the migratory phenotype in response to binding $\mathrm{S} 1 \mathrm{P}$, and in the same study, gastric cells expressing predominantly S1PR 2 did not have the same chemotactic responses to S1P and did not migrate [123]. Specific inhibition of the S1PR 2 receptor by JTE-013 (refer to Figure 3) abolished the inhibitory effects of S1P in S1PR expressing gastric cells. Similarly, in mouse melanoma cells overexpression of S1PR has been demonstrated to abolish the metastatic potential whereas S1PR aggravated metastasis [139]. Conversely, SphK1/S1P elevation of S1PR 2 was shown to be associated with increased metastatic potential in the lung, breast [261] and brain [262], which is seemingly contradictory. A twist in the story and a clue to the seeming contradiction was the discovery of high S1PR causal association with recurrence, reduced survival rates and metastasis in estrogen receptor negative breast tumors [256]. This led to the further finding that SphK2/ $\mathrm{S}_{1} \mathrm{PR}_{4}$ prevented nuclear translocation of S1PR, which in turn, prevented tumor growth, providing support for sub-cellular distribution of $\mathrm{S}_{1} \mathrm{PR}_{2}$, which is important for oncogenic suppression [263]. Thus, these findings may partly explain the contradictory $\mathrm{S}_{\mathrm{PR}}$, subtype-specific regulation of metastasis, suggesting $\mathrm{SpK} / \mathrm{S} 1 \mathrm{P}$ stimulated cell migration and proliferation is dependent on the cellspecific diversity of the $\mathrm{SphK}$ and $\mathrm{S}_{1} \mathrm{PR}_{1-5}$ expression [123, 256, 261, 263, 264]. The S1PR sub-type, the level and the localization of S1PR expression is critical for the degree of cancer progression and contributes to the increasing complexity and challenges for SphK andS1PRS as oncotargets.

\section{SPHK IN CANCER DRUG RESISTANCE}

It comes as no surprise that the SphK pathway is associated with anti-cancer drug resistance given the overexpression and aberrant expression of SphKs, S1P, 
and S1PRs lead to cancer development and metastasis. Overexpression of SphKs, S1P and the S1PRs are causally associated with cancer drug resistance to conventional cancer treatments (radiotherapy, chemo- and hormone therapies) in many types of cancers, including breast [92, 230], pancreatic [265], and prostate cancers [266]. Cancer patients overexpressing SphK1 tend to have poorer survival rates [129, 223]. As discussed in this review, cancer cells can become dependent on the SphK1 enzyme for survival and proliferation, termed nononcogenic addiction. In estrogen receptor (ER) positive breast cancer cells overexpression of SphK1 increases tamoxifen resistance and ablation of SphK1 restores tamoxifen sensitivity $[92,230]$. S1P binding to $\mathrm{S}_{1} \mathrm{PR}_{3}$ is associated with $\mathrm{SphK} 1$ translocation of SphK1 to the plasma membrane to promote tumorigenesis in ER+ breast cancer [94]. In ER negative breast cancer high tumor levels of $\mathrm{S} 1 P R_{4}$ and $\mathrm{SphK} 1$ are associated with poor patient prognosis [256, 267], and in HER2+ cells $\mathrm{S}_{1} \mathrm{PR}_{4} / \mathrm{HER} 2+$ signaling is associated with metastasis [267]. Similarly overexpression of SphK1 correlates with androgen independent refractory cells [105, 268].

The mechanism for SphK-induced drug resistance is unclear, however, much effort has gone into developing anti-SphK designer drugs to overcome drug resistance as discussed in greater detail in the next section. Nonetheless, what is emerging is the complexity of SphKs isozyme and isoform expression pattern, forming the basis of this review, and how aberrant expression of these enzymes is posing problems in the design and implementation of anti-SphK drugs in the clinic. In particular we review how aberrant expression of the hSphK1 isoforms can confer resistance to SphK1 targeted drugs [25, 26, 102] highlighting the challenges faced in anti-SphK drug treatment in cancer therapy.

\section{SPHK/S1P DESIGNER DRUGS}

Since SphKs have been recognized as major driver proteins in many cancer types, there has been much interest in targeting the overexpression of human SphK1 (hSphK1)/S1P as an anticancer treatment $[11,15,27$, $48,57,60,239,269-276]$. However, the design of drugs to inhibit $\mathrm{SphK} / \mathrm{S} 1 \mathrm{P}$ action has inherent complexities due to the diversity of SphK functions and its important role(s) in normal physiology. Thus pan-SphK is not considered to be an ideal solution for cancer therapeutic targeting. Current strategies in development for cancer treatment are targeted towards designer drugs to prevent overactivity of S1P action either by selectively targeting and blocking S1P receptors [15, 78, 271, 277-279] or targeting the S1P producers, SphK1 and/or SphK2 [27, $108,275,280]$. Inhibitors of individual or combinations of $\mathrm{S}_{1 \mathrm{PR}}$, , to block specific S1PR signaling (Figure 3, Table 3), or block SphK1 and/or SphK2 catalyst activity are available and listed in Table 2 (adapted from [15, 271, 281]). There are a number of specific and non-specific
S1PR modulators currently in clinical use and clinical trials for diseases such as multiple sclerosis (primary progress and relapse remitting), autoimmune disease, inflammatory disorders, kidney transplantation rejection, liver and renal disorders, and acute stroke, and these have recently been reviewed [281]. Considering anti-SphK drugs such as the immunosuppressor prodrug FTY720 are being successfully and safely used in the clinic, adds to their appeal as anti-cancer therapy. In particular, FTY720 binding to SphK2 in the nucleus has been shown to inhibit the SphK2/histone H3/HDAC 1/2 repressor complex therefore allowing the transcription of proteins, such as p21, which mediate cell cycle arrest [249].

A number of selective sphingosine-based inhibitors and allosteric activators of SphK have been designed to combat the hyper-proliferative signaling of cancer and other diseases and the value of these compounds are reflected in the many filed patents including: Selective inhibitors and allosteric activators of sphingosine kinase, patent - WO 2014118556 A2; and amidine analogs that can inhibit activity of SphK1 and SphK2 patent - WO 2009146112 A1; long chain base sphingosine kinase inhibitors targeting hSphK1 and 2: WO 2013119946 A1, reviewed in [282].

\section{Inherent problems with SphK/S1P/S1PR designer drugs}

Targeting SphKs or specific or combinational S1PRs for cancer therapy nonetheless has inherent problems. Many of the earlier S1P and SphK inhibitors were problematic exhibiting non-specific and off-target effects and with low potency. As discussed above, individual cancer cells express different S1PRs sub-types, and these sub-types are associated with cancer development and malignancy [123, 139]. For example, as schematically shown in Figure 2, most of the S1PR modulators target $\mathrm{S}_{1} \mathrm{PR}_{1}$ however S1PR may not be expressed or be reduced in cancer cells. Furthermore, the specific interactors of the S1PRs and the location of expression of the S1PRs may dictate the cell's propensity to become malignant. Until recently SphK1 has been purported as the main driver of non-oncogenic addiction and proliferation. Albeit, recently developed compounds such as PF543, which inhibits hSphK1 with a greater potency ( $>100$-fold) than for $\mathrm{hSphK} 2$, and the dual inhibitor Amgen 82, which is proving to be the most potent dual inhibitor available, reduce S1P production, but do not induce cytotoxicity in cancer cells at pharmaceutically relevant concentrations, undermining their clinical application in cancer therapy $[27,276]$. As shown in 1483 head and neck cancer cell lines tested PF543 failed to increase ceramide, which is essential for apoptosis induction [286]. Another perceived disadvantage of the SphK1 inhibitor PF543 was discovered when it was administered to mice and exacerbated an inflammatory response [56]. 
Focus is now drawn to inhibition of hSphK2 and the most studied is the specific SphK2 inhibitor, ABC294640 compound [282], now in phase I/II clinical trials (Table 4). Compound ABC294640 has been shown to effectively suppress proliferation accompanied by a decrease in intracellular S1P levels and an increase in ceramide [46]. Although this drug has shown significant efficacy in cancer cell and animal models, as mentioned previously, the specificity of ABC294640 is questionable. As Pyne and colleagues discovered ABC294640 induced proteosomal degradation of the SphK1a isoform in HEK293T and androgen-independent prostate cancer cell lines showing ABC294640 was not a specific SphK2 target (cited in [56]). Second generation SphK2 inhibitors such as SLR080811 are even more potent, however, antiintuitively, SLR080811 inhibition of SphK2, increases circulating S1P levels significantly, which has potential negative consequences as $\mathrm{S} 1 \mathrm{P}$ has been shown to drive angiogenesis [46, 282].

Despite the many drug compounds developed to target the SphK pathway, anti-SphK drug design is still a challenge due to the functional plasticity of the SphK proteins which are activated by phosphorylation, protein interactions and the suggestion that their catalytic function and regulation may be dependent on conformational mobility as reviewed [48]. Also, due to the similarities and overlap in the lipid binding pockets of the enzymes in the sphingolipid metabolic pathway, achieving high specificity is difficult [48].

As will be discussed, aberrant expression of SphK1 isoforms can also affect the efficacy of current cancer therapies $[25,26]$ and may have consequences for antiSphK1 and S1P therapy in the presence of comorbid conditions $[15,28]$. Although progression has been made towards understanding the $\mathrm{SphK} / \mathrm{S} 1 \mathrm{P} / \mathrm{S} 1 \mathrm{PR}$ pathways, this has also opened a Pandora's box. As listed in Tables 2 and 3 a plethora of SphK/S1P/S1PR modulators have been developed. Optimistically, a few of these SphK modulators are now in Phase I and II clinical trial for cancer treatment (Table 4), nonetheless very few of these modulators to-date have been approved for clinical use for cancer therapy.

\section{DISCOVERY OF SPHK1 ISOFORMS IN MOUSE AND HUMANS}

There is undisputable evidence to support a significant role for aberrant SphK1 and SphK2 isozyme expression in cancer development. Despite a huge body of basic research and studies on the biochemical regulation of the SphK pathways, there has been a delay in the introduction of drugs that target SphK function for cancer therapy into the clinic. There is now supporting evidence to suggest that aberrant expression and/or inappropriate cellular localization of SphK1 and SphK2 isoforms contribute to both oncogenicity and anti-cancer treatment resistance. The following sections review the characterization of the $\mathrm{SphK}$ isoforms and their potential oncogenic role and prognostic significance of SphK1 and SphK2 isoform expression.

\section{Characterization of the mouse SphK1 isoforms}

SphK1 and SphK2 isozymes are both expressed as variant isoforms in mice and humans. Murine SphK1 (mSphK1) was the first mammalian SphK to be cloned and shares amino acid sequence homology with the corresponding Caenorhabditis elegans (c. elegans), and yeast counterparts [23]. Much of the early characterization of the mammalian SphK was derived from the mouse model. MSphK1 is ubiquitously expressed in many different mouse tissues but at differing levels, depending on the tissue type $[23,333]$. Two similar $\mathrm{mSphK} 1$ isoforms, $\mathrm{mSphK} 1 \mathrm{a}$ and $\mathrm{mSphK1b}$, identified by the Spiegel group, were found to differ only at the N-terminal where the $\mathrm{mSphK} 1 \mathrm{~b}$ isoform was identified to be seven amino acids longer than the 1a isoform, however showing an actual 10 amino acid difference overall (Figure 4) [23]. Despite the strong sequence similarities the enzymatic traits of the two lipid kinases were found to be very different [334]. Compared to mSphK1a, mSphK1b was shown to differ in cellular location, oligomerization properties and posttranslational modifications [334]. SphK1b was observed to be more unstable than the 1a isoform and even though the predicted mass of the b- isoform was $43.3 \mathrm{kDa}$, when run on SDS-PAGE exhibited an unusually fast mobility and the band was detected at $34 \mathrm{kDa}$ [334]. This suggested that the native conformational structures of the two isoforms were vastly different, and the b-isoform has an SDSresistant structure. Although the 3 dimensional structures of the mSphK isoforms have not been characterized, the catalytic domain is adjacent to the N-terminus and the proposed conformational differences between the isoforms are likely to contribute to the differences in enzymatic traits. Although there are only few differences in the amino acid sequences of mSPHK $1 \mathrm{a}$ and $\mathrm{mSPHK} 1 \mathrm{~b}$ [333], the mSphK1a isoforms exhibit 3-fold greater activity than the mSphK $1 b$ isoform. The $m S p h K 1 b$ isoform, which is located predominantly on the plasma membrane, was found to be more unstable compared to the 1a-isoform and did not accumulate in the cell [334]. Treatment with the proteasome inhibitor MG132 slightly increased the abundance of the mSphK1a isoform whereas the effect on mSphK1b abundance was significantly increased, suggesting involvement of the proteasome in the differential degradation of the two $\mathrm{mSphK} 1$ isoforms [334]. Site-directed mutagenesis of unique Cys residues in the $\mathrm{mSphK} 1 \mathrm{~b}$ isoform led to an increase in $\mathrm{mSphK} 1 \mathrm{~b}$ activity and prevented membranous degradation of $\mathrm{mSphK} 1 \mathrm{~b}$ upon addition of proteasome inhibitors [334]. Interestingly, mSphK1a was more susceptible to degradation when membrane bound suggesting it was 
the ability of isoform binding to the membrane that was responsible for $\mathrm{mSphK} 1$ protein stability [334]. Structural differences were also observed between the $-1 \mathrm{a}$ and $-1 \mathrm{~b}$ isoforms whereby $\mathrm{mSphK} 1 \mathrm{~b}$ was mainly found as homooligomers and mSphK1a isoforms were mainly observed as monomers, allowing a greater diversity of cellular function [334].

It was only in 2006 that a third murine mSphK1 isoform, mSphK1a2, was reported [334]. In comparison to $\mathrm{mSphK} 1 \mathrm{a}$, the SphK1a2 isoform contains an extra valine (Val) residue due to an insertion of three base pairs in the coding- region. Thus mSphK1a contains the sequence Met-Glu-Pro whereas the mSPHK1a2 isoform has the sequence is Met-Glu-Pro-Val revealing a greater similarity between $\mathrm{mSphK} 1 \mathrm{a} 2$ and $\mathrm{mSphK} 1 \mathrm{~b}$ (Figure 4a). The mSphK1a2 isoform had very similar stability and function to its $\mathrm{mSphK} 2$ counterpart and was the most ubiquitously expressed, followed by $\mathrm{mSphK} 1 \mathrm{a}$ and $\mathrm{mSphK} 1 \mathrm{~b}$ in decreasing order of abundance [334]. Much of our biological characterization of the SphK isoforms is derived from murine models however, although there is high amino acid sequence homology between the human and mouse SphK proteins at the C-terminal, there are vast differences in the $\mathrm{N}$-terminal sequences and apparent differences in the ligand binding pockets between the different SphK1 isoforms of mammalian species (Figure 4). Thus, while great inroads to $\mathrm{SphK}$ function have been acquired through studying the murine models, the functionality of $\mathrm{hSphK}$ isoforms cannot directly be compared to $\mathrm{mSphK}$ isoforms due to their profound differences at the N-terminal [271]. Here we focus on what is known about the human $\mathrm{SphK}(\mathrm{hSphK})$ isoforms and the further challenges associated with targeting SphK/ $\mathrm{S} 1 \mathrm{P}$ as a therapeutic target for multiple diseases.

\section{Characterization of human SphK1 (hSphK1) isoforms}

A putative hSphK1 was predicted in 1998 sharing sequence homology with $c$. elegans, yeast and murine SphK1 sequences [23], however the hSphK1 was not sequenced and characterized until 2000 [206, 335]. Due to the high homology in the hSphK1 C-terminal of all the mammalian species sequenced, hSphK1 could be identified immunohistochemically in human tissue using a rabbit polyclonal antibody, thus confirming the diversity of hSphK1 expression in different tissue types [333]. Using Northern blot analysis, hSphK1 was observed to be widely expressed in human tissues with highest expression levels in adult liver, kidney, heart and skeletal muscle [335]. Since the first discovery of human SphK1, three unique isoforms of the hSphK1 have been identified to date varying only at the N-terminus: hSphK1a (NM_001142601, Q9NYA1); hSphK1b (NM_182965: Q9NYA-2) and hSphK1c (NM_021972: Q9AYA1-3), the
Genbank $^{\mathrm{TM}}$ and Uniprot accession numbers, respectively, have been provided. Both hSphK1a and hSphK1c are similar in size $(42.5 \mathrm{kDa}$ and $43.9 \mathrm{kDa}$ respectively) with the 1c-isoform having an additional 14 amino acids at the N-terminus (Figure 4b). Both hSphK-1a and -1c have similar mobility on SDS PAGE and in some reports have been referred to as hSphK1a and hSphK $1 \mathrm{a}+14$ to distinguish between the two isoforms [25]. The hSphK1b $(51 \mathrm{kDa})$ isoform contains a unique upstream 86 amino acid sequence at the N-terminal region (Figure $4 \mathrm{~b}$ ). It is noted that in some reports the $\mathrm{hSphK} 1 \mathrm{c}$ isoform refers to the longer isoform (470 amino acids) and the $\mathrm{hSphKb}$ isoform refers to hSphKc (398 amino acids) [53]. For this review, the convention will refer to $\mathrm{hSphK} 1 \mathrm{~b}$ as the $51 \mathrm{kDa}$ (470 amino acids).

Much of the literature does not specify the human SphK1 isoform used in the reported studies, and most in vitro studies have conventionally used the shorter hSphK1a isoform to determine structure and function of hSphK1 in the cell [48]. To-date few reports have defined the distribution of the hSphK1 isoforms in cells, or in different tissue types, and most studies use stable or transient overexpression of the hSphK1 isoforms to define their biological significance. Using overexpression of hSphK1 isoforms in human cells $\mathrm{hSphK}-1 \mathrm{a}$ and $-1 \mathrm{~b}$ isoforms have been demonstrated to have similar S1P activity $[25,28,53]$ and both isoforms translocate to the plasma membrane [25]. However, what is emerging is that there are functional differences in the activity of the human SphK1 isoforms. Hla and colleagues provide evidence showing hSphKla is preferentially secreted from cells and activates extracellular S1P/S1PR ${ }_{1}$, whereas $\mathrm{hSphK} 1 \mathrm{~b}$ and hSphK1c are more likely to be retained in the plasma cell membrane [53]. The suggestion is that hSphKa may contribute to the establishment of the vascular S1P gradient and vascular integrity under normal physiological conditions. As the SphK rheostat is involved in inflammation [336], it is possible that hSphK1a has a distinct role in inflammatory disease.

\section{Common and specific interactions of human SphK1 isoforms}

Studies using the hSphK1b isoform suggest that the extra 86 amino acids at the $\mathrm{N}$-terminal may contribute to conformational changes relevant to the diversity of SphK1 function and may impact on efficacy of hSphK1 directed drug administration and outcome $[15,57,271]$. As far as we are aware, there is only one study to-date that used a multiplex-based stable isotope labeling with amino acids in cell culture (SILAC) co-immunoprecipitation to identify unique and common interacting partners of the two major $\mathrm{hSphK}$ isoforms (1a and $1 \mathrm{~b}$ ) elucidating possible ways by which these interactions may influence cancer pathophysiology [28]. Gene ontology analysis 
of the functional roles for the interacting partners of the two isoforms showed strong similarities demonstrating common functions as expected. Of major interest is the difference in the interactions conferred by the unique extra 86 amino acids of the hSphK1b, which not only allows specific binding to the unique upstream $\mathrm{N}$-terminal region but also confers conformational differences between the two isoforms affecting specific binding affinity. The PP2A serine/threonine phosphatase, one of the most well characterized hSphK1 partners responsible for deactivating SphK bound with greater affinity to the hSphKa (43kDa) isoform. As expected, in this study, most of the isoform specific interactions were associated with the hSphK $1 \mathrm{~b}$ isoform. These interactions included various proteasomal sub-units, and latent-transforming growth factor $\beta$-binding protein 1 . The unique putative proteasomal binding sites suggest that this isoform may be more susceptible to proteasomal degradation in a breast cancer cell line. This observation was supported by a prominent increase in the $\mathrm{hSphK} 1 \mathrm{~b}$ isoform upon treatment with the proteasomal inhibitor MG132 whereas hSphK1a protein levels showed little change post treatment indicating $\mathrm{hSphK} 1 \mathrm{~b}$ has a higher protein turnover than hSphK1a in cells [28].

Although specific functions for each of the SphK1 isoforms have yet to be identified in vitro and in vivo we have some evidence to suggest unravelling the individual and common or overlapping functions SphK1 isoforms will add further complexity to targeting SphK in cancer treatment. A full list of the reported SphK1a $(43 \mathrm{kDa})$ and SphK1b $(51 \mathrm{kDa})$ interactors can be found in [28]. In these studies by McGowan and colleagues the SphK1a $(51 \mathrm{kDa})$ and the SphK1b $(43 \mathrm{kDa})$ isoforms were independently, stably overexpressed. To-date, no studies have looked at the likelihood and potential effects of hSphK1 heterodimerization (hSphK1a-hSphK1b) and their interactors. These types of dimerization studies would add to our knowledge of the structural plasticity of SphK1, add to the repertoire of protein-interactions, and increase our understanding of the extensive downstream functions and cellular effects of SphK1 isoforms. As recently highlighted by Adams, Pyne and Pyne [48] the catalytic function and enzyme regulation through $\mathrm{SphK} 1$ is likely to be dependent on conformational mobility and an understanding the dynamic changes in hSphK1 structure will provide more avenues for the development of SphK modulators in targeted cancer therapy.

\section{hSphK1b isoform - a link between diabetes and cancer treatments}

An important hSphK1b-specific interactor identified was the dipeptidyl peptidase 2 (DPP2), which is involved in the regulation of glucose metabolism [28]. DPP2/4 inhibitors block degradation of hSphK1b but have no effect on the hSphK1a isoform. As DPP inhibitors are used in diabetic treatment, these treatments would increase the propensity towards elevated hSphK1b and S1P activity. The suggestion that DPP inhibitors may increase cancer risk and increased S1P activity has been reported as a mediator of oncogenicity: highlighting the "ying and yang" of comorbidity treatments (reviewed in [15]).

\section{hSphK1 isoform specific anti-SphK drug efficacy}

Previous studies have shown the involvement of the proteasome in the regulation of $\mathrm{hSphK} 1$, where novel inhibitors of SphK1-S1P activity induced the proteasomal degradation of this protein in prostate cancer cell lines [266]. Androgen-independent prostate cancer cell lines demonstrate higher levels of SphK- 1a and 1b than androgen sensitive prostate cells $[25,266]$. Further studies demonstrated proteasome regulation and degradation of hSphK1 was isoform dependent and cell-type specific $[25,26,102]$. These studies clearly show that cellular phenotypic changes in cell lines also affected proteasomal degradation and stabilization of the two major hSphK isoforms, which in turn affect anti-SphK drug efficacy. As demonstrated in prostate cancer cell lines, hSphK1b was less sensitive to proteasomal degradation in androgenindependent LNCaP-A1 cells compared to $\mathrm{LNCaP}$ androgen-sensitive cells $[25,26]$. The inhibitor of the SphK1 and SphK2 isozymes, SKi (2-(p-hydroxyanilino)4-(p-chlorophenyl) thiazole)) induced proteosomal degradation of hSphK1a and hSphK1b in androgensensitive prostate cancer cells, however failed to promote degradation of hSphK1b in androgen-independent prostate cancer cells. The apparent inability of the Ski inhibitor to affect the $\mathrm{hSphK} 1 \mathrm{~b}$ expression in androgen-independent cells was found to be due to a compensatory increase in hSphK1b mRNA expression [25].

Indeed, further studies demonstrated that the inhibitor of SphK2, ABC294640 (3-(4-chlorophenyl)adamantane-1-carboxylic acid (pyridin- 4-ylmethyl) amide) was able to reduce the expression of SphK1a in androgen-independent LNCaP-AI cells and this was prevented by pre-treating these cells with the proteasomal inhibitor, MG132 [102]. Overall the major findings from these challenging studies are 1) the ubiquitin-proteasomal degradation of hSphK1 is important in cell survival, 2) differential proteasomal degradation of hSphK1a and $\mathrm{hSphK} 1 \mathrm{~b}$ is cell-phenotype specific, 3) differential regulation of $h \mathrm{SphK} 1 \mathrm{a}$ and $\mathrm{hSphK} 1 \mathrm{~b}$ may contribute to anti-SphK/S1P therapy resistance as demonstrated in prostate cancer cells $[25,26]$.

Although these studies provide some insight into the distribution of SphK1 in human tissues and the importance of SphK1 in disease, to date there have been no explicit studies on the relative expression levels of the variant SphK1 isoforms in human tissue, providing some open and very pertinent questions that are yet to be answered. The caveat of most in vitro studies is the reliance on studies of the overexpression of SphK1 in 
stable cell lines and may not truly reflect SphK1 isoform expression in normal physiological or tissue samples. It is currently unknown whether one or both isoforms are expressed in normal cells and whether changes in isoform expression levels occur in, or contribute to, disease states (i.e. in normal cells and cancer cells and different disease states). Determining the relative expression levels of each of theSphK1 isoforms may reveal novel roles for the two major SphK1 isoforms in cancer and other disease development and/or progression.

\section{CHARACTERIZATION OF HSPHK2 ISOFORMS AND THE POTENTIAL OF HSPHK2B AS AN ONCOTARGET}

The SphK2 isozyme is gaining much prominence as a cancer therapeutic target and may prove to have greater efficacy as an oncotarget than its comparative isozyme $\mathrm{hSphK} 1$, which is driving the development of the hSphK2 inhibitors (Table 2), and the ongoing clinical trials of the hSphK2 ABC294640 (Table 4). However, we know little about the structure and function of SphK2 and even less regarding the hSphK2 isoforms. The SphK2a genes were cloned in both murine and humans in 2000 and the comparison is shown in Figure 6 [16]. Interestingly, the SphK2b isoform is not expressed in the mouse therefore functional isoform-specific studies have been limited to cell lines [337]. The SphK2 encodes at least 4 predicted variants [a-d] however 5 isoforms have been annotated: isoform 1 'a' (NM_020126; Q9NRA0-1); isoform 2 ' $b$ ' (NM_001204158.2; Q9NRA0-2); isoform 3 'a' (NM_001204159.2; Q9NRA0-3); isoform 4 'c' (NM_001204160.2; Q9NRA0-4); and isoform 5 ' $\mathrm{d}$ ' (NM_001243876.1; Q9NRA0-5); the Genbank ${ }^{\mathrm{TM}}$ and the Uniprot accession numbers, respectively, are provided. Note: transcripts for isoform 1 and 3 encode the same isoform ' $a$ '. Comparison of SphK2a-d is illustrated in Figure 6.

The hSphK2a and -b isoforms have been confirmed with the b-isoform containing 36 extra amino acids at the N-terminal, the $\mathrm{c}$ and $\mathrm{d}$ isoforms are predicted [46]. The hSphK2-a, b and c isoforms contain five conserved catalytic regions (nominated C1-C5) whereas SphK2d does not possess two of these catalytic regions (C4-C5) and therefore is most probably inactive [46]. Original studies in human cell lines refer to the longer isoform (b-isoform), containing the additional 36 amino acids at the N-terminus, as hSphK2-L and the short isoform (a-isoform) as hSphK2-S [337]. Firstly, the longer isoform was found to be predominant in the human cell lines tested and secondly, these studies defined distinct differences in the physiological role of the N-terminal extension of $\mathrm{hSphK} 2$. To-date hSphK2 isoforms have been reported to differ in their subcellular localization with isoform 1 ' $a$ ' located in the cytoplasm and the membrane, and isoform
2 'b' reported to be located at the lysosome membrane \{reference: ncbi.nim.nih.gov;gene:56848]. Billich and colleagues presented data showing that hSphK2-L was involved in the regulation of cell proliferation and apoptosis in serum deprivation and this was cell-type dependent [337].

Based on kinetic studies, the N-terminal extension of the human SphK2b (hSphK2-L) has been reported to be responsible for more efficient binding to FTY720, a sphingosine analog, with more effective activation than the shorter isoforms [248]. This observation is interesting due to the use of FTY720 currently in the clinic for multiple sclerosis and its promise in cancer therapy. Hence, SphK2b may prove to be a more effective anticancer target in vivo. Work to characterize the functions of the known isoforms is an ongoing requirement for our understanding of the cellular roles of these isoforms and their contribution to disease states and the existence of additional SphK2 variants remains a possibility.

\section{SPHK/S1PRS AS DIAGNOSTIC OR THERAPEUTIC MOLECULAR BIOMARKERS IN CANCER}

Given the considerable evidence showing increased SphK1/S1P/S1PRs is present in many types of cancer, as discussed in this review and others [98, 223, 338, 339], there is the potential for SphK isozymes, isoforms and S1P and S1PRs as potential new biomarkers for clinical diagnosis and prognosis, for early cancer detection, as an indicator of progression and tumor aggressiveness. Prime examples include breast, cervical, prostate, head and neck, and brain cancers. Overexpression of SphK1 and differential S1PRs distribution are associated with poor prognosis and disease stage in breast cancer and may prove to be strong candidates as diagnostic and prognositic markers for $\mathrm{ER}+$ and ER- breast cancers, endocrine resistance, and metastasis [11, 230, 340]. In cervical cancer SphK1 was significantly increased in comparison to normal tissues and patients had a higher probability of recurrence and lower overall survival [130]. Likewise overexpression of SphK1 is found in aggressive gliomas and is associated with poor survival [341].

Nevertheless, SphK1 overexpression is not an indicator for all cancers. Measurement of SphK/S1P and S1PR levels as a cancer diagnostic marker has to be carefully considered as biomarkers as overexpression is not necessarily related to poorer prognosis. In prostate cancer decreased levels of circulating S1P was reported during prostate cancer progression potentially stemming from a significant decrease in erythrocyte SphK1 levels, and this S1P decrease correlates with high prostate specific antigen (PSA) levels, lymph node status and may be an early marker for androgen independent tumors [339]. As discussed above, SphK2 is also gaining ground as a 
marker of cancer progression [107, 220].

In summary, although SphK1 is highly expressed in many cancer cell types, compared to its contemporary cell type, its suitability as a diagnostic or therapeutic biomarker for all cancers is still unknown. For some cell types it may be an indicator of cancer development and of resistance to conventional cancer therapies. As highlighted in this review, aberrant $\mathrm{SphK}$ isozyme and isoform expression levels and cellular localization, differential $\mathrm{S}_{\mathrm{PR}} \mathrm{PR}_{1-5}$ expression, and intracellular and extracellular S1P levels are all associated with cancer initiation, development, progression and metastasis. Further profiling and characterization of the SphK pathway will provide a more detailed analysis for future diagnosis and prognosis in the various cancer-types. The feasibility and complexity of developing a method to detect SphK/S1P/S1PRs as biomarkers in the clinical samples, such as blood samples, is another consideration in the future.

\section{KEY ISSUES AND FUTURE CHALLENGES FOR SPHK AS AN ONCOTARGET}

Disruption of the SphK rheostat is now well recognized as a hallmark of cancer development and an instigator of cancer treatment resistance. Nonetheless, SphK balance of sphingosine to S1P is necessary for normal cell physiology so ablating the function of SphK has clinical concerns for deleterious off-target effects.

In this review we have provided an overview of the promise, and the problems, of targeting SphKs, S1P and S1PRs as novel cancer treatments and outlined the approach of pharmacologically targeting SphK1 and/or SphK2 to alter their activity so that clinically beneficial changes in cancer patients can be achieved. In the absence of mutations in SphK and S1PRs it has been difficult to determine the extent of their involvement in cancer and non-oncogenic addiction has been proposed as the mechanism driving SphK-associated malignancy. Hence, the term drugging the addict(s) (SphK1, SphK2 and S1PRs) has been the driving force for novel cancer drug design. As listed in Tables 2 and 3 there is no paucity to the growing list of anti-SphK, anti-S1P, and anti-S1PRs modulators, of which some are in clinical trials, Table 4. While SphK/S1PR modulators hold much promise as additional novel cancer therapies, as indicated in this review, there are still many challenges facing antiSphK drug use in cancer therapy. Although SphK1 has historically been described as a pro-proliferative lipid enzyme, whereas SphK2 has been described for its proapoptotic effects, in practice inhibitors of SphK1 have failed to induce apoptosis whilst the hSphK2 inhibitors, $\mathrm{ABC} 294640$ and FTY720, are proving to be more efficacious inhibitors of cell proliferation. Interestingly, the observation that FTY720 binds more efficiently to the unique $\mathrm{N}$-terminal of the $\mathrm{SphK} 2 \mathrm{~b}$ isoform suggests that the unique SphK2 N-terminal domain may be a more attractive oncotarget such that isoform-specific inhibitors can be designed. Nevertheless, inhibition of SphK2 by some SphK2 inhibitors demonstrated increase in S1P production, and the physiological consequences of this increase are unknown. Adding to the complexity of SphKs role in cancer, aberrant SphK isozyme localization has been cited as potentially contributing to carcinogenesis. Although much insight has been gained from studying SphK isozymes and isoforms in mouse models there are inherent major differences between human and mouse $\mathrm{SphK}$ isoforms. More recent attention has been focused on the human SphK isoforms, especially since the discovery that androgen independent prostate cancer cells expressing $\mathrm{hSphK} 1 \mathrm{~b}$ isoform are refractory to SphK1 inhibitors. Very little is known of the physiology and mechanism of SphK isoforms in culture and clinical samples, such as if one or both isoforms are present in cells and if the physiology of enzymatic regulation is dependent on the dynamic changes in isoform expression and interactions. Understanding the structural conformational plasticity of SphK1 isoforms through homo- and hetero- dimerization and how this relates to normal function and disease will provide more options for SphK oncotarget potential.

In conclusion, although there is great excitement in developing SphK/S1P/S1PR modulators for cancer treatment the intricacies of the SphK pathways are still being unraveled. New knowledge gained from the study of the human SphK isozymes, and in particular human SphK isoforms biology, will provide more understanding of SphKs role in cancer progression, metastasis, and drug resistance, allowing for the development of more specific and effective anti-SphK oncotargets.

\section{ACKNOWLEDGMENTS}

DH is the recipient of an Australia Postgraduate Award scholarship and Cancer Institute of New South Wales Scholarship (Translational Cancer Research Network, Sydney Vital). NH is the recipient of a UTS Research Scholarship (UTS IRS), University of Technology Sydney.

\section{CONFLICTS OF INTEREST}

The authors of this manuscript declare no conflict of interest.

\section{REFERENCES}

1. Pulkoski-Gross MJ, Donaldson JC, Obeid LM. Sphingosine1-phsphate metabolism: A structural perspective. Crit Rev Biochem Mol Biol. 2015; 50:298-313.

2. Maceyka M, Harikumar KB, Milstien S, Spiegel S. Sphingosine-1-phosphate signaling and its role in disease. 
Trends Cell Biol. 2012; 22:50-60.

3. Pyne S, Pyne NJ. New perspectives on the role of sphingosine 1-phosphate in cancer. Handb Exp Pharmacol. 2013; 216:55-71.

4. Pitson SM. Regulation of sphingosine kinase and sphingolipid signaling. Trends Biochem Sci. 2011; 36:97-107.

5. Cuvillier O, Pirianov G, Kleuser B, Vanek PG, Coso OA, Gutkind S, Spiegel S. Suppression of ceramide-mediated programmed cell death by sphingosine-1-phosphate. Nature. 1996; 381:800-03.

6. Gómez-Muñoz A, Waggoner DW, O’Brien L, Brindley DN. Interaction of ceramides, sphingosine, and sphingosine 1-phosphate in regulating DNA synthesis and phospholipase D activity. J Biol Chem. 1995; 270:26318-25.

7. Pyne S, Pyne NJ. The differential regulation of cyclic AMP by sphingomyelin-derived lipids and the modulation of sphingolipid-stimulated extracellular signal regulated kinase-2 in airway smooth muscle. Biochem J. 1996; 315:917-23.

8. Mendelson K, Evans T, Hla T. Sphingosine 1-phosphate signalling. Development. 2014; 141:5-9.

9. Pyne S, Tolan DG, Conway AM, Pyne N. Sphingolipids as differential regulators of cellular signalling processes. Biochem Soc Trans. 1997; 25:549-56.

10. Spiegel S, Milstien S. Sphingosine-1-phosphate: an enigmatic signalling lipid. Nat Rev Mol Cell Biol. 2003; 4:397-407.

11. Maczis M, Milstien S, Spiegel S. Sphingosine-1-phosphate and estrogen signaling in breast cancer. Adv Biol Regul. 2016; 60:160-65.

12. Sukocheva O, Wadham C. Role of sphingolipids in oestrogen signalling in breast cancer cells: an update. J Endocrinol. 2014; 220:R25-35.

13. Mastrandrea LD, Sessanna SM, Laychock SG. Sphingosine kinase activity and sphingosine-1 phosphate production in rat pancreatic islets and INS-1 cells: response to cytokines. Diabetes. 2005; 54:1429-36.

14. Martin JL, Lin MZ, McGowan EM, Baxter RC. Potentiation of growth factor signaling by insulin-like growth factorbinding protein-3 in breast epithelial cells requires sphingosine kinase activity. J Biol Chem. 2009; 284:2554252.

15. Haass NK, Nassif N, McGowan EM. Switching the sphingolipid rheostat in the treatment of diabetes and cancer comorbidity from a problem to an advantage. Biomed Res Int. 2015; 2015:165105.

16. Liu H, Sugiura M, Nava VE, Edsall LC, Kono K, Poulton S, Milstien S, Kohama T, Spiegel S. Molecular cloning and functional characterization of a novel mammalian sphingosine kinase type 2 isoform. J Biol Chem. 2000; 275:19513-20.

17. Alemany R, van Koppen CJ, Danneberg K, Ter Braak M, Meyer $\mathrm{Zu}$ Heringdorf D. Regulation and functional roles of sphingosine kinases. Naunyn Schmiedebergs Arch Pharmacol. 2007; 374:413-28.
18. Pyne NJ, Pyne S. Sphingosine 1-phosphate and cancer. Nat Rev Cancer. 2010; 10:489-503.

19. Mizugishi K, Yamashita T, Olivera A, Miller GF, Spiegel S, Proia RL. Essential role for sphingosine kinases in neural and vascular development. Mol Cell Biol. 2005; 25:1111321.

20. Michaud J, Kohno M, Proia RL, Hla T. Normal acute and chronic inflammatory responses in sphingosine kinase 1 knockout mice. FEBS Lett. 2006; 580:4607-12.

21. Allende ML, Sasaki T, Kawai H, Olivera A, Mi Y, van Echten-Deckert G, Hajdu R, Rosenbach M, Keohane CA, Mandala S, Spiegel S, Proia RL. Mice deficient in sphingosine kinase 1 are rendered lymphopenic by FTY720. J Biol Chem. 2004; 279:52487-92.

22. Maceyka M, Sankala H, Hait NC, Le Stunff H, Liu H, Toman R, Collier C, Zhang M, Satin LS, Merrill AH Jr, Milstien S, Spiegel S. SphK1 and SphK2, sphingosine kinase isoenzymes with opposing functions in sphingolipid metabolism. J Biol Chem. 2005; 280:37118-29.

23. Kohama T, Olivera A, Edsall L, Nagiec MM, Dickson R, Spiegel S. Molecular cloning and functional characterization of murine sphingosine kinase. J Biol Chem. 1998; 273:23722-28.

24. Liu H, Chakravarty D, Maceyka M, Milstien S, Spiegel S. Sphingosine kinases: a novel family of lipid kinases. Prog Nucleic Acid Res Mol Biol. 2002; 71:493-511.

25. Loveridge $\mathrm{C}$, Tonelli $\mathrm{F}$, Leclercq $\mathrm{T}$, Lim KG, Long JS, Berdyshev E, Tate RJ, Natarajan V, Pitson SM, Pyne NJ, Pyne S. The sphingosine kinase 1 inhibitor 2-(p-hydroxyanilino)-4-(p-chlorophenyl)thiazole induces proteasomal degradation of sphingosine kinase 1 in mammalian cells. J Biol Chem. 2010; 285:38841-52.

26. Lim KG, Tonelli F, Berdyshev E, Gorshkova I, Leclercq T, Pitson SM, Bittman R, Pyne S, Pyne NJ. Inhibition kinetics and regulation of sphingosine kinase 1 expression in prostate cancer cells: functional differences between sphingosine kinase 1a and 1b. Int J Biochem Cell Biol. 2012; 44:1457-64.

27. Santos WL, Lynch KR. Drugging sphingosine kinases. ACS Chem Biol. 2015; 10:225-33.

28. Yagoub D, Wilkins MR, Lay AJ, Kaczorowski DC, Hatoum D, Bajan S, Hutvagner G, Lai JH, Wu W, Martiniello-Wilks R, Xia P, McGowan EM. Sphingosine kinase 1 isoformspecific interactions in breast cancer. Mol Endocrinol. 2014; 28:1899-915.

29. Olivera A, Spiegel S. Sphingosine kinase: a mediator of vital cellular functions. Prostaglandins Other Lipid Mediat. 2001; 64:123-34.

30. Payne SG, Milstien S, Spiegel S. Sphingosine-1-phosphate: dual messenger functions. FEBS Lett. 2002; 531:54-57.

31. Blaho VA, Hla T. An update on the biology of sphingosine 1-phosphate receptors. J Lipid Res. 2014; 55:1596-608.

32. Yan G, Chen S, You B, Sun J. Activation of sphingosine kinase-1 mediates induction of endothelial cell proliferation 
and angiogenesis by epoxyeicosatrienoic acids. Cardiovasc Res. 2008; 78:308-14.

33. Proia RL, Hla T. Emerging biology of sphingosine-1phosphate: its role in pathogenesis and therapy. J Clin Invest. 2015; 125:1379-87.

34. Liu Y, Wada R, Yamashita T, Mi Y, Deng CX, Hobson JP, Rosenfeldt HM, Nava VE, Chae SS, Lee MJ, Liu CH, Hla T, Spiegel S, et al. Edg-1, the G protein-coupled receptor for sphingosine-1-phosphate, is essential for vascular maturation. J Clin Invest. 2000; 106:951-61.

35. Gomez L, Paillard M, Price M, Chen Q, Teixeira G, Spiegel S, Lesnefsky EJ. A novel role for mitochondrial sphingosine-1-phosphate produced by sphingosine kinase-2 in PTP-mediated cell survival during cardioprotection. Basic Res Cardiol. 2011; 106:1341-53.

36. Yung LM, Wei Y, Qin T, Wang Y, Smith CD, Waeber C. Sphingosine kinase 2 mediates cerebral preconditioning and protects the mouse brain against ischemic injury. Stroke. 2012; 43:199-204.

37. Strub GM, Paillard M, Liang J, Gomez L, Allegood JC, Hait NC, Maceyka M, Price MM, Chen Q, Simpson DC, Kordula T, Milstien S, Lesnefsky EJ, et al. Sphingosine-1-phosphate produced by sphingosine kinase 2 in mitochondria interacts with prohibitin 2 to regulate complex IV assembly and respiration. FASEB J. 2011; 25:600-12.

38. Takabe K, Paugh SW, Milstien S, Spiegel S. "Inside-out" signaling of sphingosine-1-phosphate: therapeutic targets. Pharmacol Rev. 2008; 60:181-95.

39. Spiegel S, Milstien S. Sphingosine-1-phosphate: signaling inside and out. FEBS Lett. 2000; 476:55-57.

40. Chun J, Goetzl EJ, Hla T, Igarashi Y, Lynch KR, Moolenaar W, Pyne S, Tigyi G. International Union of Pharmacology. XXXIV. Lysophospholipid receptor nomenclature. Pharmacol Rev. 2002; 54:265-69.

41. Takuwa Y, Takuwa N, Sugimoto N. The Edg family G protein-coupled receptors for lysophospholipids: their signaling properties and biological activities. J Biochem. 2002; 131:767-71.

42. Ishii I, Friedman B, Ye X, Kawamura S, McGiffert C, Contos JJ, Kingsbury MA, Zhang G, Brown JH, Chun J. Selective loss of sphingosine 1-phosphate signaling with no obvious phenotypic abnormality in mice lacking its $G$ proteincoupled receptor, LP(B3)/EDG-3. J Biol Chem. 2001; 276:33697-704.

43. Strub GM, Maceyka M, Hait NC, Milstien S, Spiegel S. Extracellular and intracellular actions of sphingosine-1phosphate. Adv Exp Med Biol. 2010; 688:141-55.

44. Pitson SM, D'andrea RJ, Vandeleur L, Moretti PA, Xia P, Gamble JR, Vadas MA, Wattenberg BW. Human sphingosine kinase: purification, molecular cloning and characterization of the native and recombinant enzymes. Biochem J. 2000; 350:429-41.

45. Pitson SM, Moretti PA, Zebol JR, Vadas MA, D'Andrea RJ, Wattenberg BW. A point mutant of human sphingosine kinase 1 with increased catalytic activity. FEBS Lett. 2001; 509:169-73.

46. Neubauer HA, Pitson SM. Roles, regulation and inhibitors of sphingosine kinase 2. FEBS J. 2013; 280:5317-36.

47. Gao P, Peterson YK, Smith RA, Smith CD. Characterization of isoenzyme-selective inhibitors of human sphingosine kinases. PLoS One. 2012; 7:e44543.

48. Adams DR, Pyne S, Pyne NJ. Sphingosine Kinases: Emerging Structure-Function Insights. Trends Biochem Sci. 2016; 41:395-409.

49. Igarashi N, Okada T, Hayashi S, Fujita T, Jahangeer S, Nakamura S. Sphingosine kinase 2 is a nuclear protein and inhibits DNA synthesis. J Biol Chem. 2003; 278:46832-39.

50. Fukuda Y, Kihara A, Igarashi Y. Distribution of sphingosine kinase activity in mouse tissues: contribution of SPHK1. Biochem Biophys Res Commun. 2003; 309:155-60.

51. Shen H, Giordano F, Wu Y, Chan J, Zhu C, Milosevic I, Wu X, Yao K, Chen B, Baumgart T, Sieburth D, De Camilli $\mathrm{P}$. Coupling between endocytosis and sphingosine kinase 1 recruitment. Nat Cell Biol. 2014; 16:652-62.

52. Zemann B, Urtz N, Reuschel R, Mechtcheriakova D, Bornancin F, Badegruber R, Baumruker T, Billich A. Normal neutrophil functions in sphingosine kinase type 1 and 2 knockout mice. Immunol Lett. 2007; 109:56-63.

53. Venkataraman K, Thangada S, Michaud J, Oo ML, Ai Y, Lee YM, Wu M, Parikh NS, Khan F, Proia RL, Hla T. Extracellular export of sphingosine kinase-1a contributes to the vascular S1P gradient. Biochem J. 2006; 397:461-71.

54. Pyne S, Lee SC, Long J, Pyne NJ. Role of sphingosine kinases and lipid phosphate phosphatases in regulating spatial sphingosine 1-phosphate signalling in health and disease. Cell Signal. 2009; 21:14-21.

55. Pitson SM, Moretti PA, Zebol JR, Lynn HE, Xia P, Vadas MA, Wattenberg BW. Activation of sphingosine kinase 1 by ERK1/2-mediated phosphorylation. EMBO J. 2003; 22:5491-500.

56. Pyne NJ, McNaughton M, Boomkamp S, MacRitchie N, Evangelisti C, Martelli AM, Jiang HR, Ubhi S, Pyne S. Role of sphingosine 1-phosphate receptors, sphingosine kinases and sphingosine in cancer and inflammation. Adv Biol Regul. 2016; 60:151-59.

57. Pyne S, Adams DR, Pyne NJ. Sphingosine 1-phosphate and sphingosine kinases in health and disease: recent advances. Prog Lipid Res. 2016; 62:93-106.

58. Sun N, Keep RF, Hua Y, Xi G. Critical Role of the Sphingolipid Pathway in Stroke: a Review of Current Utility and Potential Therapeutic Targets. Transl Stroke Res. 2016; 7:420-38.

59. Petrache I, Berdyshev EV. Ceramide Signaling and Metabolism in Pathophysiological States of the Lung. Annu Rev Physiol. 2016; 78:463-80.

60. Nema R, Vishwakarma S, Agarwal R, Panday RK, Kumar A. Emerging role of sphingosine-1-phosphate signaling in head and neck squamous cell carcinoma. Onco Targets 
Ther. 2016; 9:3269-80.

61. Gomez-Muñoz A, Presa N, Gomez-Larrauri A, Rivera IG, Trueba M, Ordoñez M. Control of inflammatory responses by ceramide, sphingosine 1-phosphate and ceramide 1-phosphate. Prog Lipid Res. 2016; 61:51-62.

62. Suh JH, Saba JD. Sphingosine-1-phosphate in inflammatory bowel disease and colitis-associated colon cancer: the fat's in the fire. Transl Cancer Res. 2015; 4:469-83.

63. Zheng S, Wei S, Wang X, Xu Y, Xiao Y, Liu H, Jia J, Cheng J. Sphingosine kinase 1 mediates neuroinflammation following cerebral ischemia. Exp Neurol. 2015; 272:160 69.

64. Taha TA, Hannun YA, Obeid LM. Sphingosine kinase: biochemical and cellular regulation and role in disease. $\mathrm{J}$ Biochem Mol Biol. 2006; 39:113-31.

65. Oskeritzian CA, Milstien S, Spiegel S. Sphingosine-1phosphate in allergic responses, asthma and anaphylaxis. Pharmacol Ther. 2007; 115:390-99.

66. Maceyka M, Milstien S, Spiegel S. Sphingosine-1-phosphate: the Swiss army knife of sphingolipid signaling. J Lipid Res. 2009 (Suppl); 50:S272-76.

67. Obinata H, Hla T. Sphingosine 1-phosphate in coagulation and inflammation. Semin Immunopathol. 2012; 34:73-91.

68. Brenner C, Galluzzi L, Kepp O, Kroemer G. Decoding cell death signals in liver inflammation. J Hepatol. 2013; 59:583-94.

69. Ariga T, Jarvis WD, Yu RK. Role of sphingolipid-mediated cell death in neurodegenerative diseases. J Lipid Res. 1998; 39:1-16.

70. Sivasubramanian M, Kanagaraj N, Dheen ST, Tay SS. Sphingosine kinase 2 and sphingosine-1-phosphate promotes mitochondrial function in dopaminergic neurons of mouse model of Parkinson's disease and in MPP+ -treated MN9D cells in vitro. Neuroscience. 2015; 290:63648.

71. Cox TM, Rosenbloom BE, Barker RA. Gaucher disease and comorbidities: b-cell malignancy and parkinsonism. Am J Hematol. 2015 (Suppl 1); 90:S25-28.

72. Milstien S, Gude D, Spiegel S. Sphingosine 1-phosphate in neural signalling and function. Acta Paediatr. 2007; 96:40 43.

73. Urtz N, Gaertner F, von Bruehl ML, Chandraratne S, Rahimi F, Zhang L, Orban M, Barocke V, Beil J, Schubert I, Lorenz M, Legate KR, Huwiler A, et al. Sphingosine 1-phosphate produced by sphingosine kinase 2 intrinsically controls platelet aggregation in vitro and in vivo. Circ Res. 2015; 117:376-87.

74. Zhang L, Urtz N, Gaertner F, Legate KR, Petzold T, Lorenz M, Mazharian A, Watson SP, Massberg S. Sphingosine kinase 2 (Sphk2) regulates platelet biogenesis by providing intracellular sphingosine 1-phosphate (S1P). Blood. 2013; 122:791-802.

75. Yu H, Yuan L, Xu M, Zhang Z, Duan H. Sphingosine kinase 1 improves cutaneous wound healing in diabetic rats.
Injury. 2014; 45:1054-58.

76. Qi Y, Chen J, Lay A, Don A, Vadas M, Xia P. Loss of sphingosine kinase 1 predisposes to the onset of diabetes via promoting pancreatic $\beta$-cell death in diet-induced obese mice. FASEB J. 2013; 27:4294-304.

77. Vessey DA, Li L, Jin ZQ, Kelley M, Honbo N, Zhang J, Karliner JS. A sphingosine kinase form 2 knockout sensitizes mouse myocardium to ischemia/reoxygenation injury and diminishes responsiveness to ischemic preconditioning. Oxid Med Cell Longev. 2011; 2011:961059.

78. Kunkel GT, Maceyka M, Milstien S, Spiegel S. Targeting the sphingosine-1-phosphate axis in cancer, inflammation and beyond. Nat Rev Drug Discov. 2013; 12:688-702.

79. Nagahashi M, Hait NC, Maceyka M, Avni D, Takabe K, Milstien S, Spiegel S. Sphingosine-1-phosphate in chronic intestinal inflammation and cancer. Adv Biol Regul. 2014; 54:112-20.

80. Kawamori T, Kaneshiro T, Okumura M, Maalouf S, Uflacker A, Bielawski J, Hannun YA, Obeid LM. Role for sphingosine kinase 1 in colon carcinogenesis. FASEB J. 2009; 23:405-14.

81. Pyne NJ, Pyne S. Sphingosine 1-phosphate is a missing link between chronic inflammation and colon cancer. Cancer Cell. 2013; 23:5-7.

82. Gaire BP. Sphingosine kinase 2 as the promising target for stroke research. Int J Stroke. 2016 Jan 5. [Epub ahead of print].

83. Pfeilschifter W, Czech-Zechmeister B, Sujak M, Mirceska A, Koch A, Rami A, Steinmetz H, Foerch C, Huwiler A, Pfeilschifter J. Activation of sphingosine kinase 2 is an endogenous protective mechanism in cerebral ischemia. Biochem Biophys Res Commun. 2011; 413:212-17.

84. Wacker BK, Perfater JL, Gidday JM. Hypoxic preconditioning induces stroke tolerance in mice via a cascading HIF, sphingosine kinase, and CCL2 signaling pathway. J Neurochem. 2012; 123:954-62.

85. Wacker BK, Freie AB, Perfater JL, Gidday JM. Junctional protein regulation by sphingosine kinase 2 contributes to blood-brain barrier protection in hypoxic preconditioninginduced cerebral ischemic tolerance. J Cereb Blood Flow Metab. 2012; 32:1014-23.

86. Wacker BK, Park TS, Gidday JM. Hypoxic preconditioninginduced cerebral ischemic tolerance: role of microvascular sphingosine kinase 2. Stroke. 2009; 40:3342-48.

87. Karliner JS. Sphingosine kinase and sphingosine 1-phosphate in the heart: a decade of progress. Biochim Biophys Acta. 2013; 1831:203-12.

88. Rana A, Sharma S. Mechanism of sphingosine-1-phosphate induced cardioprotection against I/R injury in diabetic rat heart: possible involvement of glycogen synthase kinase $3 \beta$ and mitochondrial permeability transition pore. Clin Exp Pharmacol Physiol. 2016; 43:166-73.

89. Martin JL, de Silva HC, Lin MZ, Scott CD, Baxter RC. 
Inhibition of insulin-like growth factor-binding protein-3 signaling through sphingosine kinase-1 sensitizes triplenegative breast cancer cells to EGF receptor blockade. Mol Cancer Ther. 2014; 13:316-28.

90. Sukocheva OA, Wang L, Albanese N, Pitson SM, Vadas MA, Xia P. Sphingosine kinase transmits estrogen signaling in human breast cancer cells. Mol Endocrinol. 2003; 17:2002-12.

91. Sukocheva O, Wadham C, Holmes A, Albanese N, Verrier E, Feng F, Bernal A, Derian CK, Ullrich A, Vadas MA, Xia P. Estrogen transactivates EGFR via the sphingosine 1-phosphate receptor Edg-3: the role of sphingosine kinase-1. J Cell Biol. 2006; 173:301-10.

92. Watson C, Long JS, Orange C, Tannahill CL, Mallon E, McGlynn LM, Pyne S, Pyne NJ, Edwards J. High expression of sphingosine 1-phosphate receptors, S1P1 and S1P3, sphingosine kinase 1, and extracellular signalregulated kinase-1/2 is associated with development of tamoxifen resistance in estrogen receptor-positive breast cancer patients. Am J Pathol. 2010; 177:2205-15.

93. Nava VE, Hobson JP, Murthy S, Milstien S, Spiegel S. Sphingosine kinase type 1 promotes estrogen-dependent tumorigenesis of breast cancer MCF-7 cells. Exp Cell Res. 2002; 281:115-27.

94. Long JS, Edwards J, Watson C, Tovey S, Mair KM, Schiff R, Natarajan V, Pyne NJ, Pyne S. Sphingosine kinase 1 induces tolerance to human epidermal growth factor receptor 2 and prevents formation of a migratory phenotype in response to sphingosine 1-phosphate in estrogen receptor-positive breast cancer cells. Mol Cell Biol. 2010; 30:3827-41.

95. Wang F, Van Brocklyn JR, Edsall L, Nava VE, Spiegel S. Sphingosine-1-phosphate inhibits motility of human breast cancer cells independently of cell surface receptors. Cancer Res. 1999; 59:6185-91.

96. Takabe K, Kim RH, Allegood JC, Mitra P, Ramachandran S, Nagahashi M, Harikumar KB, Hait NC, Milstien S, Spiegel $\mathrm{S}$. Estradiol induces export of sphingosine 1-phosphate from breast cancer cells via ABCC1 and ABCG2. J Biol Chem. 2010; 285:10477-86.

97. Nagahashi M, Ramachandran S, Kim EY, Allegood JC, Rashid OM, Yamada A, Zhao R, Milstien S, Zhou H, Spiegel S, Takabe K. Sphingosine-1-phosphate produced by sphingosine kinase 1 promotes breast cancer progression by stimulating angiogenesis and lymphangiogenesis. Cancer Res. 2012; 72:726-35.

98. Pyne S, Edwards J, Ohotski J, Pyne NJ. Sphingosine 1-phosphate receptors and sphingosine kinase 1: novel biomarkers for clinical prognosis in breast, prostate, and hematological cancers. Front Oncol. 2012; 2:168.

99. Pchejetski D, Golzio M, Bonhoure E, Calvet C, Doumerc N, Garcia V, Mazerolles C, Rischmann P, Teissié J, Malavaud B, Cuvillier O. Sphingosine kinase-1 as a chemotherapy sensor in prostate adenocarcinoma cell and mouse models. Cancer Res. 2005; 65:11667-75.
100. Pchejetski D, Doumerc N, Golzio M, Naymark M, Teissié J, Kohama T, Waxman J, Malavaud B, Cuvillier O. Chemosensitizing effects of sphingosine kinase-1 inhibition in prostate cancer cell and animal models. Mol Cancer Ther. 2008; 7:1836-45.

101. Pchejetski D, Böhler T, Stebbing J, Waxman J. Therapeutic potential of targeting sphingosine kinase 1 in prostate cancer. Nat Rev Urol. 2011; 8:569-678.

102. McNaughton M, Pitman M, Pitson SM, Pyne NJ, Pyne S. Proteasomal degradation of sphingosine kinase 1 and inhibition of dihydroceramide desaturase by the sphingosine kinase inhibitors, SKi or ABC294640, induces growth arrest in androgen-independent LNCaP-AI prostate cancer cells. Oncotarget. 2016; 7:16663-75. doi: 10.18632/ oncotarget.7693.

103. Malavaud B, Pchejetski D, Mazerolles C, de Paiva GR, Calvet C, Doumerc N, Pitson S, Rischmann P, Cuvillier O. Sphingosine kinase-1 activity and expression in human prostate cancer resection specimens. Eur J Cancer. 2010; 46:3417-24.

104. Gestaut MM, Antoon JW, Burow ME, Beckman BS. Inhibition of sphingosine kinase-2 ablates androgen resistant prostate cancer proliferation and survival. Pharmacol Rep. 2014; 66:174-78.

105. Dayon A, Brizuela L, Martin C, Mazerolles C, Pirot N, Doumerc N, Nogueira L, Golzio M, Teissié J, Serre G, Rischmann P, Malavaud B, Cuvillier O. Sphingosine kinase-1 is central to androgen-regulated prostate cancer growth and survival. PLoS One. 2009; 4:e8048.

106. Akao Y, Banno Y, Nakagawa Y, Hasegawa N, Kim TJ, Murate T, Igarashi Y, Nozawa Y. High expression of sphingosine kinase 1 and S1P receptors in chemotherapyresistant prostate cancer PC3 cells and their camptothecininduced up-regulation. Biochem Biophys Res Commun. 2006; 342:1284-90.

107. Wallington-Beddoe CT, Powell JA, Tong D, Pitson SM, Bradstock KF, Bendall LJ. Sphingosine kinase 2 promotes acute lymphoblastic leukemia by enhancing MYC expression. Cancer Res. 2014; 74:2803-15.

108. Xu L, Zhang Y, Gao M, Wang G, Fu Y. Concurrent targeting Akt and sphingosine kinase 1 by A-674563 in acute myeloid leukemia cells. Biochem Biophys Res Commun. 2016; 472:662-68.

109. Sobue S, Nemoto S, Murakami M, Ito H, Kimura A, Gao S, Furuhata A, Takagi A, Kojima T, Nakamura M, Ito Y, Suzuki M, Banno Y, et al. Implications of sphingosine kinase 1 expression level for the cellular sphingolipid rheostat: relevance as a marker for daunorubicin sensitivity of leukemia cells. Int J Hematol. 2008; 87:266-75.

110. Marfe G, Di Stefano C, Gambacurta A, Ottone T, Martini V, Abruzzese E, Mologni L, Sinibaldi-Salimei P, de Fabritis P, Gambacorti-Passerini C, Amadori S, Birge RB. Sphingosine kinase 1 overexpression is regulated by signaling through PI3K, AKT2, and mTOR in imatinibresistant chronic myeloid leukemia cells. Exp Hematol. 
2011; 39: 653-665 e656.

111. Kennedy AJ, Mathews TP, Kharel Y, Field SD, Moyer ML, East JE, Houck JD, Lynch KR, Macdonald TL. Development of amidine-based sphingosine kinase 1 nanomolar inhibitors and reduction of sphingosine 1-phosphate in human leukemia cells. J Med Chem. 2011; 54:3524-48.

112. Zhu L, Wang Z, Lin Y, Chen Z, Liu H, Chen Y, Wang N, Song $X$. Sphingosine kinase 1 enhances the invasion and migration of non-small cell lung cancer cells via the AKT pathway. Oncol Rep. 2015; 33:1257-63.

113. Zhao Y, Kalari SK, Usatyuk PV, Gorshkova I, He D, Watkins T, Brindley DN, Sun C, Bittman R, Garcia JG, Berdyshev EV, Natarajan V. Intracellular generation of sphingosine 1-phosphate in human lung endothelial cells: role of lipid phosphate phosphatase-1 and sphingosine kinase 1. J Biol Chem. 2007; 282:14165-77.

114. Wang Q, Li J, Li G, Li Y, Xu C, Li M, Xu G, Fu S. Prognostic significance of sphingosine kinase 2 expression in non-small cell lung cancer. Tumour Biol. 2014; 35:36368.

115. Song L, Xiong H, Li J, Liao W, Wang L, Wu J, Li M. Sphingosine kinase-1 enhances resistance to apoptosis through activation of $\mathrm{PI} 3 \mathrm{~K} / \mathrm{Akt} / \mathrm{NF}-\kappa \mathrm{B}$ pathway in human non-small cell lung cancer. Clin Cancer Res. 2011; 17:1839-49.

116. Johnson KR, Johnson KY, Crellin HG, Ogretmen B, Boylan AM, Harley RA, Obeid LM. Immunohistochemical distribution of sphingosine kinase 1 in normal and tumor lung tissue. J Histochem Cytochem. 2005; 53:1159-66.

117. Aoki H, Aoki M, Katsuta E, Ramanathan R, Idowu MO, Spiegel S, Takabe K. Host sphingosine kinase 1 worsens pancreatic cancer peritoneal carcinomatosis. J Surg Res. 2016; 205:510-17.

118. Guo YX, Ma YJ, Han L, Wang YJ, Han JA, Zhu Y. Role of sphingosine 1-phosphate in human pancreatic cancer cells proliferation and migration. Int J Clin Exp Med. 2015; 8:20349-54.

119. Japtok L, Schmitz EI, Fayyaz S, Krämer S, Hsu LJ, Kleuser B. Sphingosine 1-phosphate counteracts insulin signaling in pancreatic $\beta$-cells via the sphingosine 1-phosphate receptor subtype 2. FASEB J. 2015; 29:3357-69.

120. Taguchi Y, Allende ML, Mizukami H, Cook EK, Gavrilova O, Tuymetova G, Clarke BA, Chen W, Olivera A, Proia RL. Sphingosine-1-phosphate Phosphatase 2 Regulates Pancreatic Islet $\beta$-Cell Endoplasmic Reticulum Stress and Proliferation. J Biol Chem. 2016; 291:12029-38.

121. Salama MF, Carroll B, Adada M, Pulkoski-Gross M, Hannun YA, Obeid LM. A novel role of sphingosine kinase-1 in the invasion and angiogenesis of VHL mutant clear cell renal cell carcinoma. FASEB J. 2015; 29:280313.

122. Liu SQ, Huang JA, Qin MB, Su YJ, Lai MY, Jiang HX, Tang GD. Sphingosine kinase 1 enhances colon cancer cell proliferation and invasion by upregulating the production of MMP-2/9 and uPA via MAPK pathways. Int J Colorectal Dis. 2012; 27:1569-78.

123. Yamashita H, Kitayama J, Shida D, Yamaguchi H, Mori K, Osada M, Aoki S, Yatomi Y, Takuwa Y, Nagawa H. Sphingosine 1-phosphate receptor expression profile in human gastric cancer cells: differential regulation on the migration and proliferation. J Surg Res. 2006; 130:80-87.

124. Chen MH, Yen CC, Cheng CT, Wu RC, Huang SC, Yu CS, Chung YH, Liu CY, Chang PM, Chao Y, Chen MH, Chen YF, Chiang KC, et al. Identification of SPHK1 as a therapeutic target and marker of poor prognosis in cholangiocarcinoma. Oncotarget. 2015; 6:23594-608. doi: 10.18632/oncotarget.4335.

125. Lu Z, Xiao Z, Liu F, Cui M, Li W, Yang Z, Li J, Ye L, Zhang X. Long non-coding RNA HULC promotes tumor angiogenesis in liver cancer by up-regulating sphingosine kinase 1 (SPHK1). Oncotarget. 2016; 7:241-54. doi: 10.18632/oncotarget.6280.

126. Hong G, Baudhuin LM, Xu Y. Sphingosine-1-phosphate modulates growth and adhesion of ovarian cancer cells. FEBS Lett. 1999; 460:513-18.

127. Lee JW, Ryu JY, Yoon G, Jeon HK, Cho YJ, Choi JJ, Song SY, Do IG, Lee YY, Kim TJ, Choi CH, Kim BG, Bae DS. Sphingosine kinase 1 as a potential therapeutic target in epithelial ovarian cancer. Int J Cancer. 2015; 137:221-29.

128. Beach JA, Aspuria PJ, Cheon DJ, Lawrenson K, Agadjanian H, Walsh CS, Karlan BY, Orsulic S. Sphingosine kinase 1 is required for TGF- $\beta$ mediated fibroblastto- myofibroblast differentiation in ovarian cancer. Oncotarget. 2016; 7:416782. doi: 10.18632/oncotarget.6703.

129. White MD, Chan L, Antoon JW, Beckman BS. Targeting ovarian cancer and chemoresistance through selective inhibition of sphingosine kinase-2 with ABC294640. Anticancer Res. 2013; 33:3573-79.

130. Kim HS, Yoon G, Ryu JY, Cho YJ, Choi JJ, Lee YY, Kim TJ, Choi CH, Song SY, Kim BG, Bae DS, Lee JW. Sphingosine kinase 1 is a reliable prognostic factor and a novel therapeutic target for uterine cervical cancer. Oncotarget. 2015; 6:26746-56. doi: 10.18632/ oncotarget. 4818 .

131. Quint K, Stiel N, Neureiter D, Schlicker HU, Nimsky C, Ocker M, Strik H, Kolodziej MA. The role of sphingosine kinase isoforms and receptors S1P1, S1P2, S1P3, and S1P5 in primary, secondary, and recurrent glioblastomas. Tumour Biol. 2014; 35:8979-89.

132. Bien-Möller S, Lange S, Holm T, Böhm A, Paland H, Küpper J, Herzog S, Weitmann K, Havemann C, Vogelgesang S, Marx S, Hoffmann W, Schroeder HW, et al. Expression of S1P metabolizing enzymes and receptors correlate with survival time and regulate cell migration in glioblastoma multiforme. Oncotarget. 2016; 7:13031-46. doi: 10.18632/oncotarget.7366.

133. Zhang H, Li W, Sun S, Yu S, Zhang M, Zou F. Inhibition 
of sphingosine kinase 1 suppresses proliferation of glioma cells under hypoxia by attenuating activity of extracellular signal-regulated kinase. Cell Prolif. 2012; 45:167-75.

134. Van Brocklyn JR, Jackson CA, Pearl DK, Kotur MS, Snyder PJ, Prior TW. Sphingosine kinase-1 expression correlates with poor survival of patients with glioblastoma multiforme: roles of sphingosine kinase isoforms in growth of glioblastoma cell lines. J Neuropathol Exp Neurol. 2005; 64:695-705.

135. Paugh BS, Bryan L, Paugh SW, Wilczynska KM, Alvarez SM, Singh SK, Kapitonov D, Rokita H, Wright S, Griswold-Prenner I, Milstien S, Spiegel S, Kordula T. Interleukin-1 regulates the expression of sphingosine kinase 1 in glioblastoma cells. J Biol Chem. 2009; 284:3408-17.

136. Douglas G, Kaczorowski D, McGowan E, Anfosso A, Xia $\mathrm{P}$, Weninger W, Haass NK. Modification of the sphingosine kinase pathway as a novel therapeutic approach for melanoma. Exp Dermatol. 2010.

137. Kienzle A, McGowan E, Douglas G, Kaczorowski D, Weninger W, Haass NK. Real-time cell cycle and cell death imaging of the effect of sphingosine kinase inhibition on 3D melanoma spheroids. Exp Dermatol. 2016.

138. Madhunapantula SV, Hengst J, Gowda R, Fox TE, Yun JK, Robertson GP. Targeting sphingosine kinase-1 to inhibit melanoma. Pigment Cell Melanoma Res. 2012; 25:259-74.

139. Yamaguchi H, Kitayama J, Takuwa N, Arikawa K, Inoki I, Takehara K, Nagawa H, Takuwa Y. Sphingosine-1phosphate receptor subtype-specific positive and negative regulation of Rac and haematogenous metastasis of melanoma cells. Biochem J. 2003; 374:715-22.

140. Pyszko JA, Strosznajder JB. The key role of sphingosine kinases in the molecular mechanism of neuronal cell survival and death in an experimental model of Parkinson's disease. Folia Neuropathol. 2014; 52:260-69.

141. Pyszko J, Strosznajder JB. Sphingosine kinase 1 and sphingosine-1-phosphate in oxidative stress evoked by 1-methyl-4-phenylpyridinium (MPP+) in human dopaminergic neuronal cells. Mol Neurobiol. 2014; 50:3848.

142. Leist M, Nicotera P. Apoptosis, excitotoxicity, and neuropathology. Exp Cell Res. 1998; 239:183-201.

143. France-Lanord V, Brugg B, Michel PP, Agid Y, Ruberg M. Mitochondrial free radical signal in ceramide-dependent apoptosis: a putative mechanism for neuronal death in Parkinson's disease. J Neurochem. 1997; 69:1612-21.

144. Ceccom J, Loukh N, Lauwers-Cances V, Touriol C, Nicaise Y, Gentil C, Uro-Coste E, Pitson S, Maurage CA, Duyckaerts C, Cuvillier O, Delisle MB. Reduced sphingosine kinase-1 and enhanced sphingosine 1-phosphate lyase expression demonstrate deregulated sphingosine 1-phosphate signaling in Alzheimer's disease. Acta Neuropathol Commun. 2014; 2:12.

145. He X, Huang Y, Li B, Gong CX, Schuchman EH. Deregulation of sphingolipid metabolism in Alzheimer's disease. Neurobiol Aging. 2010; 31:398-408.

146. Toman RE, Milstien S, Spiegel S. Sphingosine-1-phosphate: an emerging therapeutic target. Expert Opin Ther Targets. 2001; 5:109-23.

147. Mielke MM, Lyketsos CG. Alterations of the sphingolipid pathway in Alzheimer's disease: new biomarkers and treatment targets? Neuromolecular Med. 2010; 12:331-40.

148. Murphy MP, LeVine H 3rd. Alzheimer's disease and the amyloid- $\beta$ peptide. J Alzheimers Dis. 2010; 19:311-23.

149. Salminen A, Kauppinen A, Suuronen T, Kaarniranta K, Ojala J. ER stress in Alzheimer's disease: a novel neuronal trigger for inflammation and Alzheimer's pathology. J Neuroinflammation. 2009; 6:41.

150. Hoozemans JJ, van Haastert ES, Nijholt DA, Rozemuller AJ, Eikelenboom P, Scheper W. The unfolded protein response is activated in pretangle neurons in Alzheimer's disease hippocampus. Am J Pathol. 2009; 174:1241-51.

151. Tanzi RE, Bertram L. Twenty years of the Alzheimer's disease amyloid hypothesis: a genetic perspective. Cell. 2005; 120:545-55.

152. Katayama T, Imaizumi K, Manabe T, Hitomi J, Kudo T, Tohyama M. Induction of neuronal death by ER stress in Alzheimer's disease. J Chem Neuroanat. 2004; 28:67-78.

153. Huang Y, Tanimukai H, Liu F, Iqbal K, Grundke-Iqbal I, Gong CX. Elevation of the level and activity of acid ceramidase in Alzheimer's disease brain. Eur J Neurosci. 2004; 20:3489-97.

154. Katsel P, Li C, Haroutunian V. Gene expression alterations in the sphingolipid metabolism pathways during progression of dementia and Alzheimer's disease: a shift toward ceramide accumulation at the earliest recognizable stages of Alzheimer's disease? Neurochem Res. 2007; 32:845-56.

155. Cutler RG, Pedersen WA, Camandola S, Rothstein JD, Mattson MP. Evidence that accumulation of ceramides and cholesterol esters mediates oxidative stress-induced death of motor neurons in amyotrophic lateral sclerosis. Ann Neurol. 2002; 52:448-57.

156. Haughey NJ, Cutler RG, Tamara A, McArthur JC, Vargas DL, Pardo CA, Turchan J, Nath A, Mattson MP. Perturbation of sphingolipid metabolism and ceramide production in HIV-dementia. Ann Neurol. 2004; 55:257-67.

157. Lan T, Shen X, Liu P, Liu W, Xu S, Xie X, Jiang Q, Li W, Huang H. Berberine ameliorates renal injury in diabetic C57BL/6 mice: involvement of suppression of SphK-S1P signaling pathway. Arch Biochem Biophys. 2010; 502:11220.

158. Ma MM, Chen JL, Wang GG, Wang H, Lu Y, Li JF, Yi J, Yuan YJ, Zhang QW, Mi J, Wang LS, Duan HF, Wu CT. Sphingosine kinase 1 participates in insulin signalling and regulates glucose metabolism and homeostasis in KK/Ay diabetic mice. Diabetologia. 2007; 50:891-900.

159. Bruce CR, Risis S, Babb JR, Yang C, Kowalski GM, Selathurai A, Lee-Young RS, Weir JM, Yoshioka K, Takuwa Y, Meikle PJ, Pitson SM, Febbraio MA. 
Overexpression of sphingosine kinase 1 prevents ceramide accumulation and ameliorates muscle insulin resistance in high-fat diet-fed mice. Diabetes. 2012; 61:3148-55.

160. Hasan NM, Longacre MJ, Stoker SW, Kendrick MA, Druckenbrod NR, Laychock SG, Mastrandrea LD, MacDonald MJ. Sphingosine kinase 1 knockdown reduces insulin synthesis and secretion in a rat insulinoma cell line. Arch Biochem Biophys. 2012; 518:23-30.

161. Tao C, Sifuentes A, Holland WL. Regulation of glucose and lipid homeostasis by adiponectin: effects on hepatocytes, pancreatic $\beta$ cells and adipocytes. Best Pract Res Clin Endocrinol Metab. 2014; 28:43-58.

162. Iwatsuka H, Shino A, Suzuoki Z. General survey of diabetic features of yellow KK mice. Endocrinol Jpn. 1970; 17:2335.

163. Grundy SM, Benjamin IJ, Burke GL, Chait A, Eckel RH, Howard BV, Mitch W, Smith SC Jr, Sowers JR. Diabetes and cardiovascular disease: a statement for healthcare professionals from the American Heart Association. Circulation. 1999; 100:1134-46.

164. Turinsky J, O’Sullivan DM, Bayly BP. 1,2-Diacylglycerol and ceramide levels in insulin-resistant tissues of the rat in vivo. J Biol Chem. 1990; 265:16880-85.

165. Jessup CF, Bonder CS, Pitson SM, Coates PT. The sphingolipid rheostat: a potential target for improving pancreatic islet survival and function. Endocr Metab Immune Disord Drug Targets. 2011; 11:262-272.

166. Chavez JA, Knotts TA, Wang LP, Li G, Dobrowsky RT, Florant GL, Summers SA. A role for ceramide, but not diacylglycerol, in the antagonism of insulin signal transduction by saturated fatty acids. J Biol Chem. 2003; 278:10297-303.

167. Powell DJ, Turban S, Gray A, Hajduch E, Hundal HS. Intracellular ceramide synthesis and protein kinase Czeta activation play an essential role in palmitate-induced insulin resistance in rat L6 skeletal muscle cells. Biochem J. 2004; 382:619-29.

168. Schmitz-Peiffer C, Craig DL, Biden TJ. Ceramide generation is sufficient to account for the inhibition of the insulin-stimulated PKB pathway in $\mathrm{C} 2 \mathrm{C} 12$ skeletal muscle cells pretreated with palmitate. J Biol Chem. 1999; 274:24202-10.

169. Summers SA, Garza LA, Zhou H, Birnbaum MJ. Regulation of insulin-stimulated glucose transporter GLUT4 translocation and Akt kinase activity by ceramide. Mol Cell Biol. 1998; 18:5457-64.

170. Holland WL, Knotts TA, Chavez JA, Wang LP, Hoehn KL, Summers SA. Lipid mediators of insulin resistance. Nutr Rev. 2007 (Suppl 1); 65:S39-46.

171. Adams JM 2nd, Pratipanawatr T, Berria R, Wang E, DeFronzo RA, Sullards MC, Mandarino LJ. Ceramide content is increased in skeletal muscle from obese insulinresistant humans. Diabetes. 2004; 53:25-31.

172. Straczkowski M, Kowalska I, Nikolajuk A, Dzienis-
Straczkowska S, Kinalska I, Baranowski M, ZendzianPiotrowska M, Brzezinska Z, Gorski J. Relationship between insulin sensitivity and sphingomyelin signaling pathway in human skeletal muscle. Diabetes. 2004; 53:1215-21.

173. Özcan U, Cao Q, Yilmaz E, Lee AH, Iwakoshi NN, Özdelen E, Tuncman G, Görgün C, Glimcher LH, Hotamisligil GS. Endoplasmic reticulum stress links obesity, insulin action, and type 2 diabetes. Science. 2004; 306:457-61.

174. Bikman BT, Summers SA. Ceramides as modulators of cellular and whole-body metabolism. J Clin Invest. 2011; 121:4222-30.

175. McGowan EM, Simpson A, McManaman J, Boonyaratanakornkit V, Hardikar AA. Hijacking of endocrine and metabolic regulation in cancer and diabetes. Biomed Res Int. 2015; 2015:2

176. de Mello VD, Lankinen M, Schwab U, Kolehmainen M, Lehto S, Seppänen-Laakso T, Orešič M, Pulkkinen L, Uusitupa M, Erkkilä AT. Link between plasma ceramides, inflammation and insulin resistance: association with serum IL-6 concentration in patients with coronary heart disease. Diabetologia. 2009; 52:2612-15.

177. Gómez-Muñoz A, Gangoiti P, Granado MH, Arana L, Ouro A. Ceramide-1-phosphate in cell survival and inflammatory signaling. Adv Exp Med Biol. 2010; 688:118-30.

178. Pettus BJ, Bielawska A, Spiegel S, Roddy P, Hannun YA, Chalfant CE. Ceramide kinase mediates cytokine- and calcium ionophore-induced arachidonic acid release. J Biol Chem. 2003; 278:38206-13.

179. Gill JM, Sattar N. Ceramides: a new player in the inflammation-insulin resistance paradigm? Diabetologia. 2009; 52:2475-77.

180. Mitsutake S, Date T, Yokota H, Sugiura M, Kohama T, Igarashi Y. Ceramide kinase deficiency improves dietinduced obesity and insulin resistance. FEBS Lett. 2012; 586:1300-05.

181. Subramanian P, Vora M, Gentile LB, Stahelin RV, Chalfant CE. Anionic lipids activate group IVA cytosolic phospholipase A2 via distinct and separate mechanisms. J Lipid Res. 2007; 48:2701-08.

182. Maines LW, Fitzpatrick LR, Green CL, Zhuang Y, Smith CD. Efficacy of a novel sphingosine kinase inhibitor in experimental Crohn's disease. Inflammopharmacology. 2010; 18:73-85.

183. Baker DA, Barth J, Chang R, Obeid LM, Gilkeson GS. Genetic sphingosine kinase 1 deficiency significantly decreases synovial inflammation and joint erosions in murine TNF-alpha-induced arthritis. J Immunol. 2010; 185:2570-79.

184. Fitzpatrick LR, Green C, Frauenhoffer EE, French KJ, Zhuang Y, Maines LW, Upson JJ, Paul E, Donahue H, Mosher TJ, Smith CD. Attenuation of arthritis in rodents by a novel orally-available inhibitor of sphingosine kinase. Inflammopharmacology. 2011; 19:75-87. 
185. Piali L, Froidevaux S, Hess P, Nayler O, Bolli MH, Schlosser E, Kohl C, Steiner B, Clozel M. The selective sphingosine 1-phosphate receptor 1 agonist ponesimod protects against lymphocyte-mediated tissue inflammation. J Pharmacol Exp Ther. 2011; 337:547-56.

186. Niessen F, Schaffner F, Furlan-Freguia C, Pawlinski R, Bhattacharjee G, Chun J, Derian CK, Andrade-Gordon P, Rosen H, Ruf W. Dendritic cell PAR1-S1P3 signalling couples coagulation and inflammation. Nature. 2008; 452:654-58.

187. Allende ML, Bektas M, Lee BG, Bonifacino E, Kang J, Tuymetova G, Chen W, Saba JD, Proia RL. Sphingosine1-phosphate lyase deficiency produces a pro-inflammatory response while impairing neutrophil trafficking. J Biol Chem. 2011; 286:7348-58.

188. Price MM, Oskeritzian CA, Falanga YT, Harikumar KB, Allegood JC, Alvarez SE, Conrad D, Ryan JJ, Milstien $\mathrm{S}$, Spiegel S. A specific sphingosine kinase 1 inhibitor attenuates airway hyperresponsiveness and inflammation in a mast cell-dependent murine model of allergic asthma. $\mathrm{J}$ Allergy Clin Immunol. 2013; 131:501-11.e1.

189. Skoura A, Michaud J, Im DS, Thangada S, Xiong Y, Smith JD, Hla T. Sphingosine-1-phosphate receptor-2 function in myeloid cells regulates vascular inflammation and atherosclerosis. Arterioscler Thromb Vasc Biol. 2011; 31:81-85.

190. Liu Q, Rehman H, Shi Y, Krishnasamy Y, Lemasters JJ, Smith CD, Zhong Z. Inhibition of sphingosine kinase-2 suppresses inflammation and attenuates graft injury after liver transplantation in rats. PLoS One. 2012; 7:e41834.

191. Daum G, Grabski A, Reidy MA. Sphingosine 1-phosphate: a regulator of arterial lesions. Arterioscler Thromb Vasc Biol. 2009; 29:1439-43.

192. Keul P, Lucke S, von Wnuck Lipinski K, Bode C, Gräler M, Heusch G, Levkau B. Sphingosine-1-phosphate receptor 3 promotes recruitment of monocyte/macrophages in inflammation and atherosclerosis. Circ Res. 2011; 108:31423.

193. Blom T, Bäck N, Mutka AL, Bittman R, Li Z, de Lera A, Kovanen PT, Diczfalusy U, Ikonen E. FTY720 stimulates 27-hydroxycholesterol production and confers atheroprotective effects in human primary macrophages. Circ Res. 2010; 106:720-29.

194. Skoura A, Michaud J, Im DS, Thangada S, Xiong Y, Smith JD, Hla T. Sphingosine-1-phosphate receptor-2 function in myeloid cells regulates vascular inflammation and atherosclerosis. Arterioscler Thromb Vasc Biol. 2011; 31:81-85.

195. Ryan JJ, Spiegel S. The role of sphingosine-1-phosphate and its receptors in asthma. Drug News Perspect. 2008; 21:89-96.

196. Abdel Hadi L, Di Vito C, Riboni L. Fostering Inflammatory Bowel Disease: Sphingolipid Strategies to Join Forces. Mediators Inflamm. 2016; 2016:3827684.
197. Raisz LG. Pathogenesis of osteoporosis: concepts, conflicts, and prospects. J Clin Invest. 2005; 115:3318-25.

198. Ryu J, Kim HJ, Chang EJ, Huang H, Banno Y, Kim HH. Sphingosine 1-phosphate as a regulator of osteoclast differentiation and osteoclast-osteoblast coupling. EMBO J. 2006; 25:5840-51.

199. Pederson L, Ruan M, Westendorf JJ, Khosla S, Oursler MJ. Regulation of bone formation by osteoclasts involves Wnt/BMP signaling and the chemokine sphingosine-1phosphate. Proc Natl Acad Sci USA. 2008; 105:20764-69.

200. Ishii M, Egen JG, Klauschen F, Meier-Schellersheim M, Saeki Y, Vacher J, Proia RL, Germain RN. Sphingosine1-phosphate mobilizes osteoclast precursors and regulates bone homeostasis. Nature. 2009; 458:524-28.

201. Ishii M, Kikuta J, Shimazu Y, Meier-Schellersheim M, Germain RN. Chemorepulsion by blood S1P regulates osteoclast precursor mobilization and bone remodeling in vivo. J Exp Med. 2010; 207:2793-98.

202. Keul P, Sattler K, Levkau B. HDL and its sphingosine1-phosphate content in cardioprotection. Heart Fail Rev. 2007; 12:301-06.

203. Karliner JS. Sphingosine kinase regulation and cardioprotection. Cardiovasc Res. 2009; 82:184-92.

204. Karliner JS. Sphingosine kinase and sphingosine 1-phosphate in the heart: a decade of progress. Biochim Biophys Acta. 2013; 1831:203-12.

205. Xia P, Vadas MA, Rye KA, Barter PJ, Gamble JR. High density lipoproteins (HDL) interrupt the sphingosine kinase signaling pathway. A possible mechanism for protection against atherosclerosis by HDL. J Biol Chem. 1999; 274:33143-47.

206. Melendez AJ, Carlos-Dias E, Gosink M, Allen JM, Takacs L. Human sphingosine kinase: molecular cloning, functional characterization and tissue distribution. Gene. 2000; 251:19-26.

207. Zabielski P, Baranowski M, Błachnio-Zabielska A, Żendzian-Piotrowska M, Górski J. The effect of high-fat diet on the sphingolipid pathway of signal transduction in regenerating rat liver. Prostaglandins Other Lipid Mediat. 2010; 93:75-83.

208. Yang L, Yue S, Yang L, Liu X, Han Z, Zhang Y, Li L. Sphingosine kinase/sphingosine 1-phosphate (S1P)/ $\mathrm{S} 1 \mathrm{P}$ receptor axis is involved in liver fibrosis-associated angiogenesis. J Hepatol. 2013; 59:114-23.

209. Pagadala M, Kasumov T, McCullough AJ, Zein NN, Kirwan JP. Role of ceramides in nonalcoholic fatty liver disease. Trends Endocrinol Metab. 2012; 23:365-71.

210. Osawa Y, Nagaki M, Banno Y, Nozawa Y, Moriwaki H, Nakashima S. Sphingosine kinase regulates hepatoma cell differentiation: roles of hepatocyte nuclear factor and retinoid receptor. Biochem Biophys Res Commun. 2001; 286:673-77.

211. Osawa Y, Hannun YA, Proia RL, Brenner DA. Roles of AKT and sphingosine kinase in the antiapoptotic effects 
of bile duct ligation in mouse liver. Hepatology. 2005; 42:1320-28.

212. Li C, Zheng S, You H, Liu X, Lin M, Yang L, Li L. Sphingosine 1-phosphate (S1P)/S1P receptors are involved in human liver fibrosis by action on hepatic myofibroblasts motility. J Hepatol. 2011; 54:1205-13.

213. Li C, Jiang X, Yang L, Liu X, Yue S, Li L. Involvement of sphingosine 1-phosphate (SIP)/S1P3 signaling in cholestasis-induced liver fibrosis. Am J Pathol. 2009; 175:1464-72.

214. Park SW, Kim M, Kim M, D’Agati VD, Lee HT. Sphingosine kinase 1 protects against renal ischemiareperfusion injury in mice by sphingosine-1-phosphate1 receptor activation. Kidney Int. 2011; 80:1315-27.

215. Meyer zu Heringdorf D, Jakobs KH. Renal mesangial cells: moving on sphingosine kinase-1. Br J Pharmacol. 2007; 150:255-57.

216. Long DA, Price KL. Sphingosine kinase-1: a potential mediator of renal fibrosis. Kidney Int. 2009; 76:815-17.

217. Bischoff A, Czyborra P, Meyer Zu Heringdorf D, Jakobs KH, Michel MC. Sphingosine-1-phosphate reduces rat renal and mesenteric blood flow in vivo in a pertussis toxinsensitive manner. Br J Pharmacol. 2000; 130:1878-83.

218. Jackson EK. Role of sphingosine-1-phosphate in the renal medulla. Am J Physiol Renal Physiol. 2011; 301:F33-34.

219. Shida D, Takabe K, Kapitonov D, Milstien S, Spiegel S. Targeting SphK1 as a new strategy against cancer. Curr Drug Targets. 2008; 9:662-73.

220. Gao P, Smith CD. Ablation of sphingosine kinase-2 inhibits tumor cell proliferation and migration. Mol Cancer Res. 2011; 9:1509-19.

221. Xia P, Gamble JR, Wang L, Pitson SM, Moretti PA, Wattenberg BW, D’Andrea RJ, Vadas MA. An oncogenic role of sphingosine kinase. Curr Biol. 2000; 10:1527-30.

222. Kohno M, Momoi M, Oo ML, Paik JH, Lee YM, Venkataraman K, Ai Y, Ristimaki AP, Fyrst H, Sano H, Rosenberg D, Saba JD, Proia RL, et al. Intracellular role for sphingosine kinase 1 in intestinal adenoma cell proliferation. Mol Cell Biol. 2006; 26:7211-23.

223. Zhang Y, Wang Y, Wan Z, Liu S, Cao Y, Zeng Z. Sphingosine kinase 1 and cancer: a systematic review and meta-analysis. PLoS One. 2014; 9:e90362.

224. Pyne NJ, Tonelli F, Lim KG, Long J, Edwards J, Pyne S. Targeting sphingosine kinase 1 in cancer. Adv Biol Regul. 2012; 52:31-38.

225. Vadas M, Xia P, McCaughan G, Gamble J. The role of sphingosine kinase 1 in cancer: oncogene or non-oncogene addiction? Biochim Biophys Acta. 2008; 1781:442-47.

226. Solimini NL, Luo J, Elledge SJ. Non-oncogene addiction and the stress phenotype of cancer cells. Cell. 2007; 130:986-88.

227. Olivera A, Kohama T, Edsall L, Nava V, Cuvillier O, Poulton S, Spiegel S. Sphingosine kinase expression increases intracellular sphingosine-1-phosphate and promotes cell growth and survival. J Cell Biol. 1999; 147:545-58.

228. Edsall LC, Cuvillier O, Twitty S, Spiegel S, Milstien S. Sphingosine kinase expression regulates apoptosis and caspase activation in PC12 cells. J Neurochem. 2001; 76:1573-84.

229. Dai L, Qi Y, Chen J, Kaczorowski D, Di W, Wang W, Xia P. Sphingosine kinase (SphK) 1 and SphK2 play equivalent roles in mediating insulin's mitogenic action. Mol Endocrinol. 2014; 28:197-207.

230. Sukocheva O, Wang L, Verrier E, Vadas MA, Xia P. Restoring endocrine response in breast cancer cells by inhibition of the sphingosine kinase-1 signaling pathway. Endocrinology. 2009; 150:4484-92.

231. Wattenberg BW, Pitson SM, Raben DM. The sphingosine and diacylglycerol kinase superfamily of signaling kinases: localization as a key to signaling function. J Lipid Res. 2006; 47:1128-39.

232. Siow D, Wattenberg B. The compartmentalization and translocation of the sphingosine kinases: mechanisms and functions in cell signaling and sphingolipid metabolism. Crit Rev Biochem Mol Biol. 2011; 46:365-75.

233. Xia P, Wang L, Moretti PA, Albanese N, Chai F, Pitson SM, D'Andrea RJ, Gamble JR, Vadas MA. Sphingosine kinase interacts with TRAF2 and dissects tumor necrosis factor-alpha signaling. J Biol Chem. 2002; 277:7996-8003.

234. Alvarez SE, Harikumar KB, Hait NC, Allegood J, Strub GM, Kim EY, Maceyka M, Jiang H, Luo C, Kordula T, Milstien S, Spiegel S. Sphingosine-1-phosphate is a missing cofactor for the E3 ubiquitin ligase TRAF2. Nature. 2010; 465:1084-88.

235. Xiong Y, Lee HJ, Mariko B, Lu YC, Dannenberg AJ, Haka AS, Maxfield FR, Camerer E, Proia RL, Hla T. Sphingosine kinases are not required for inflammatory responses in macrophages. J Biol Chem. 2013; 288:32563-73.

236. Etemadi N, Chopin M, Anderton H, Tanzer MC, Rickard JA, Abeysekera W, Hall C, Spall SK, Wang B, Xiong Y, Hla T, Pitson SM, Bonder CS, et al. TRAF2 regulates $\mathrm{TNF}$ and NF- $\kappa \mathrm{B}$ signalling to suppress apoptosis and skin inflammation independently of Sphingosine kinase 1. eLife. 2015; 4:4.

237. Pitson SM, Xia P, Leclercq TM, Moretti PA, Zebol JR, Lynn HE, Wattenberg BW, Vadas MA. Phosphorylationdependent translocation of sphingosine kinase to the plasma membrane drives its oncogenic signalling. J Exp Med. 2005; 201:49-54.

238. LaMontagne K, Littlewood-Evans A, Schnell C, O'Reilly T, Wyder L, Sanchez T, Probst B, Butler J, Wood A, Liau G, Billy E, Theuer A, Hla T, et al. Antagonism of sphingosine1-phosphate receptors by FTY720 inhibits angiogenesis and tumor vascularization. Cancer Res. 2006; 66:221-31.

239. Neubauer HA, Pham DH, Zebol JR, Moretti PA, Peterson AL, Leclercq TM, Chan H, Powell JA, Pitman MR, Samuel MS, Bonder CS, Creek DJ, Gliddon BL, et al. An oncogenic 
role for sphingosine kinase 2. Oncotarget. 2016; 7:6488699. doi: 10.18632/oncotarget.11714.

240. Ding G, Sonoda H, Yu H, Kajimoto T, Goparaju SK, Jahangeer S, Okada T, Nakamura S. Protein kinase D-mediated phosphorylation and nuclear export of sphingosine kinase 2. J Biol Chem. 2007; 282:27493-502.

241. Hait NC, Allegood J, Maceyka M, Strub GM, Harikumar KB, Singh SK, Luo C, Marmorstein R, Kordula T, Milstien S, Spiegel S. Regulation of histone acetylation in the nucleus by sphingosine-1-phosphate. Science. 2009; 325:1254-57.

242. Panneer Selvam S, De Palma RM, Oaks JJ, Oleinik N, Peterson YK, Stahelin RV, Skordalakes E, Ponnusamy S, Garrett-Mayer E, Smith CD, Ogretmen B. Binding of the sphingolipid S1P to hTERT stabilizes telomerase at the nuclear periphery by allosterically mimicking protein phosphorylation. Sci Signal. 2015; 8:ra58.

243. Liu H, Toman RE, Goparaju SK, Maceyka M, Nava VE, Sankala H, Payne SG, Bektas M, Ishii I, Chun J, Milstien $\mathrm{S}$, Spiegel S. Sphingosine kinase type 2 is a putative BH3only protein that induces apoptosis. J Biol Chem. 2003; 278:40330-36.

244. Lim KG, Sun C, Bittman R, Pyne NJ, Pyne S. (R)-FTY720 methyl ether is a specific sphingosine kinase 2 inhibitor: effect on sphingosine kinase 2 expression in HEK 293 cells and actin rearrangement and survival of MCF-7 breast cancer cells. Cell Signal. 2011; 23:1590-95.

245. Venant H, Rahmaniyan M, Jones EE, Lu P, Lilly MB, Garrett-Mayer E, Drake RR, Kraveka JM, Smith CD, Voelkel-Johnson C. The sphingosine kinase 2 inhibitor abc294640 reduces the growth of prostate cancer cells and results in accumulation of dihydroceramides in vitro and in vivo. Mol Cancer Ther. 2015; 14:2744-52.

246. Xun C, Chen MB, Qi L, Tie-Ning Z, Peng X, Ning L, ZhiXiao C, Li-Wei W. Targeting sphingosine kinase 2 (SphK2) by ABC294640 inhibits colorectal cancer cell growth in vitro and in vivo. J Exp Clin Cancer Res. 2015; 34:94.

247. Chu JH, Gao ZH, Qu XJ. Down-regulation of sphingosine kinase 2 (SphK2) increases the effects of all-trans-retinoic acid (ATRA) on colon cancer cells. Biomed Pharmacother. 2014; 68:1089-97.

248. Billich A, Bornancin F, Dévay P, Mechtcheriakova D, Urtz N, Baumruker T. Phosphorylation of the immunomodulatory drug FTY720 by sphingosine kinases. J Biol Chem. 2003; 278:47408-15.

249. Hait NC, Avni D, Yamada A, Nagahashi M, Aoyagi T, Aoki H, Dumur CI, Zelenko Z, Gallagher EJ, Leroith D, Milstien S, Takabe K, Spiegel S. The phosphorylated prodrug FTY720 is a histone deacetylase inhibitor that reactivates ER $\alpha$ expression and enhances hormonal therapy for breast cancer. Oncogenesis. 2015; 4:e156.

250. Hait NC, Sarkar S, Le Stunff H, Mikami A, Maceyka M, Milstien S, Spiegel S. Role of sphingosine kinase 2 in cell migration toward epidermal growth factor. J Biol Chem.
$2005 ; 280: 29462-69$.

251. Dimasi DP, Pitson SM, Bonder CS. Examining the role of sphingosine kinase- 2 in the regulation of endothelial cell barrier integrity. Microcirculation. 2016; 23:248-65.

252. Paugh SW, Payne SG, Barbour SE, Milstien S, Spiegel $\mathrm{S}$. The immunosuppressant FTY720 is phosphorylated by sphingosine kinase type 2. FEBS Lett. 2003; 554:189-93.

253. Pyne NJ, Pyne S. Receptor tyrosine kinase-G-proteincoupled receptor signalling platforms: out of the shadow? Trends Pharmacol Sci. 2011; 32:443-50.

254. Goetzl EJ, Dolezalova H, Kong Y, Zeng L. Dual mechanisms for lysophospholipid induction of proliferation of human breast carcinoma cells. Cancer Res. 1999; 59:4732-37.

255. Van Brocklyn JR, Young N, Roof R. Sphingosine-1phosphate stimulates motility and invasiveness of human glioblastoma multiforme cells. Cancer Lett. 2003; 199:5360.

256. Ohotski J, Long JS, Orange C, Elsberger B, Mallon E, Doughty J, Pyne S, Pyne NJ, Edwards J. Expression of sphingosine 1-phosphate receptor 4 and sphingosine kinase 1 is associated with outcome in oestrogen receptor-negative breast cancer. Br J Cancer. 2012; 106:1453-59.

257. Chae SS, Paik JH, Allende ML, Proia RL, Hla T. Regulation of limb development by the sphingosine 1-phosphate receptor S1p1/EDG-1 occurs via the hypoxia/VEGF axis. Dev Biol. 2004; 268:441-47.

258. Lee DE, Kim JH, Choi SH, Cha JH, Bak EJ, Yoo YJ. The sphingosine-1-phosphate receptor 1 binding molecule FTY720 inhibits osteoclast formation in rats with ligatureinduced periodontitis. J Periodontal Res. 2017; 52:33-41.

259. Huang C, Ling R, Li FJ, Li EC, Huang QK, Liu BG, Ding Y, You SW. FTY720 enhances osteogenic differentiation of bone marrow mesenchymal stem cells in ovariectomized rats. Mol Med Rep. 2016; 14:927-35.

260. Yin JJ, Pollock CB, Kelly K. Mechanisms of cancer metastasis to the bone. Cell Res. 2005; 15:57-62.

261. Ponnusamy S, Selvam SP, Mehrotra S, Kawamori T, Snider AJ, Obeid LM, Shao Y, Sabbadini R, Ogretmen B. Communication between host organism and cancer cells is transduced by systemic sphingosine kinase 1/sphingosine 1-phosphate signalling to regulate tumour metastasis. EMBO Mol Med. 2012; 4:761-75.

262. Young N, Van Brocklyn JR. Roles of sphingosine-1phosphate (S1P) receptors in malignant behavior of glioma cells. Differential effects of S1P2 on cell migration and invasiveness. Exp Cell Res. 2007; 313:1615-27.

263. Ohotski J, Rosen H, Bittman R, Pyne S, Pyne NJ. Sphingosine kinase 2 prevents the nuclear translocation of sphingosine 1-phosphate receptor-2 and tyrosine 416 phosphorylated c-Src and increases estrogen receptor negative MDA-MB-231 breast cancer cell growth: the role of sphingosine 1-phosphate receptor-4. Cell Signal. 2014; 26:1040-47. 
264. Ohotski J, Edwards J, Elsberger B, Watson C, Orange C, Mallon E, Pyne S, Pyne NJ. Identification of novel functional and spatial associations between sphingosine kinase 1, sphingosine 1-phosphate receptors and other signaling proteins that affect prognostic outcome in estrogen receptor-positive breast cancer. Int J Cancer. 2013; 132:605-16.

265. Guillermet-Guibert J, Davenne L, Pchejetski D, SaintLaurent N, Brizuela L, Guilbeau-Frugier C, Delisle MB, Cuvillier O, Susini C, Bousquet C. Targeting the sphingolipid metabolism to defeat pancreatic cancer cell resistance to the chemotherapeutic gemcitabine drug. Mol Cancer Ther. 2009; 8:809-20.

266. Tonelli F, Lim KG, Loveridge C, Long J, Pitson SM, Tigyi G, Bittman R, Pyne S, Pyne NJ. FTY720 and (S)-FTY720 vinylphosphonate inhibit sphingosine kinase 1 and promote its proteasomal degradation in human pulmonary artery smooth muscle, breast cancer and androgen-independent prostate cancer cells. Cell Signal. 2010; 22:1536-42.

267. Long JS, Fujiwara Y, Edwards J, Tannahill CL, Tigyi G, Pyne S, Pyne NJ. Sphingosine 1-phosphate receptor 4 uses HER2 (ERBB2) to regulate extracellular signal regulated kinase-1/2 in MDA-MB-453 breast cancer cells. J Biol Chem. 2010; 285:35957-66.

268. Sauer L, Nunes J, Salunkhe V, Skalska L, Kohama T, Cuvillier O, Waxman J, Pchejetski D. Sphingosine kinase 1 inhibition sensitizes hormone-resistant prostate cancer to docetaxel. Int J Cancer. 2009; 125:2728-36.

269. Takabe K, Spiegel S. Export of sphingosine-1-phosphate and cancer progression. J Lipid Res. 2014; 55:1839-46.

270. Heffernan-Stroud LA, Obeid LM. Sphingosine kinase 1 in cancer. Adv Cancer Res. 2013; 117:201-35.

271. Pitman MR, Costabile M, Pitson SM. Recent advances in the development of sphingosine kinase inhibitors. Cell Signal. 2016; 28:1349-63.

272. Truman JP, García-Barros M, Obeid LM, Hannun YA. Evolving concepts in cancer therapy through targeting sphingolipid metabolism. Biochim Biophys Acta. 2014; 1841:1174-88.

273. Newton J, Lima S, Maceyka M, Spiegel S. Revisiting the sphingolipid rheostat: evolving concepts in cancer therapy. Exp Cell Res. 2015; 333:195-200.

274. Evangelisti C, Evangelisti C, Buontempo F, Lonetti A, Orsini E, Chiarini F, Barata JT, Pyne S, Pyne NJ, Martelli AM. Therapeutic potential of targeting sphingosine kinases and sphingosine 1-phosphate in hematological malignancies. Leukemia. 2016; 30:2142-51.

275. Gault CR, Obeid LM. Still benched on its way to the bedside: sphingosine kinase 1 as an emerging target in cancer chemotherapy. Crit Rev Biochem Mol Biol. 2011; 46:342-51.

276. Lynch KR, Thorpe SB, Santos WL. Sphingosine kinase inhibitors: a review of patent literature (2006-2015). Expert Opin Ther Pat. 2016:1-8.
277. Orr Gandy KA, Obeid LM. Targeting the sphingosine kinase/sphingosine 1-phosphate pathway in disease: review of sphingosine kinase inhibitors. Biochim Biophys Acta. 2013; 1831:157-66.

278. Milstien S, Spiegel S. Targeting sphingosine-1-phosphate: a novel avenue for cancer therapeutics. Cancer Cell. 2006; 9:148-50.

279. Dai L, Xia P, Di W. Sphingosine 1-phosphate: a potential molecular target for ovarian cancer therapy? Cancer Invest. 2014; 32:71-80.

280. Babahosseini H, Srinivasaraghavan V, Zhao Z, Gillam F, Childress E, Strobl JS, Santos WL, Zhang C, Agah M. The impact of sphingosine kinase inhibitor-loaded nanoparticles on bioelectrical and biomechanical properties of cancer cells. Lab Chip. 2016; 16:188-98.

281. Park SJ, Im DS. Sphingosine 1-Phosphate Receptor Modulators and Drug Discovery. Biomol Ther (Seoul). 2017; 25:80-90.

282. Lynch KR, Thorpe SB, Santos WL. Sphingosine kinase inhibitors: a review of patent literature (2006-2015). Expert Opin Ther Pat. 2016; 26:1409-1416.

283. Dickson MA, Carvajal RD, Merrill AH Jr, Gonen M, Cane LM, Schwartz GK. A phase I clinical trial of safingol in combination with cisplatin in advanced solid tumors. Clin Cancer Res. 2011; 17:2484-92.

284. Delgado A, Casas J, Llebaria A, Abad JL, Fabrias G. Inhibitors of sphingolipid metabolism enzymes. Biochim Biophys Acta. 2006; 1758:1957-77.

285. Vogt D, Weber J, Ihlefeld K, Brüggerhoff A, Proschak E, Stark H. Design, synthesis and evaluation of 2-aminothiazole derivatives as sphingosine kinase inhibitors. Bioorg Med Chem. 2014; 22:5354-67.

286. Schnute ME, McReynolds MD, Kasten T, Yates M, Jerome G, Rains JW, Hall T, Chrencik J, Kraus M, Cronin CN, Saabye M, Highkin MK, Broadus R, et al. Modulation of cellular S1P levels with a novel, potent and specific inhibitor of sphingosine kinase-1. Biochem J. 2012; 444:79-88.

287. Sun DF, Gao ZH, Liu HP, Yuan Y, Qu XJ. Sphingosine 1-phosphate antagonizes the effect of all-trans retinoic acid (ATRA) in a human colon cancer cell line by modulation of RAR $\beta$ expression. Cancer Lett. 2012; 319:182-89.

288. Gustin DJ, Li Y, Brown ML, Min X, Schmitt MJ, Wanska M, Wang X, Connors R, Johnstone S, Cardozo M, Cheng AC, Jeffries S, Franks B, et al. Structure guided design of a series of sphingosine kinase (SphK) inhibitors. Bioorg Med Chem Lett. 2013; 23:4608-16.

289. Kapitonov D, Allegood JC, Mitchell C, Hait NC, Almenara JA, Adams JK, Zipkin RE, Dent P, Kordula T, Milstien $\mathrm{S}$, Spiegel S. Targeting sphingosine kinase 1 inhibits Akt signaling, induces apoptosis, and suppresses growth of human glioblastoma cells and xenografts. Cancer Res. 2009; 69:6915-23.

290. Paugh SW, Paugh BS, Rahmani M, Kapitonov D, Almenara 
JA, Kordula T, Milstien S, Adams JK, Zipkin RE, Grant $\mathrm{S}$, Spiegel S. A selective sphingosine kinase 1 inhibitor integrates multiple molecular therapeutic targets in human leukemia. Blood. 2008; 112:1382-91.

291. Sharma AK. Sphingo-guanidines and their use as inhibitors of sphingosine kinase (WO2010078247). Expert Opin Ther Pat. 2011; 21:807-812.

292. Xiang Y, Hirth B, Kane JL Jr, Liao J, Noson KD, Yee C, Asmussen G, Fitzgerald M, Klaus C, Booker M. Discovery of novel sphingosine kinase-1 inhibitors. Part 2. Bioorg Med Chem Lett. 2010; 20:4550-54.

293. Lim KG, Gray AI, Pyne S, Pyne NJ. Resveratrol dimers are novel sphingosine kinase 1 inhibitors and affect sphingosine kinase 1 expression and cancer cell growth and survival. $\mathrm{Br}$ J Pharmacol. 2012; 166:1605-16.

294. Mathews TP, Kennedy AJ, Kharel Y, Kennedy PC, Nicoara O, Sunkara M, Morris AJ, Wamhoff BR, Lynch KR, Macdonald TL. Discovery, biological evaluation, and structure-activity relationship of amidine based sphingosine kinase inhibitors. J Med Chem. 2010; 53:2766-78.

295. Byun HS, Pyne S, Macritchie N, Pyne NJ, Bittman R. Novel sphingosine-containing analogues selectively inhibit sphingosine kinase (SK) isozymes, induce SK1 proteasomal degradation and reduce DNA synthesis in human pulmonary arterial smooth muscle cells. MedChemComm. 2013; 4:1394.

296. Baek DJ, MacRitchie N, Pyne NJ, Pyne S, Bittman R. Synthesis of selective inhibitors of sphingosine kinase 1 . Chem Commun (Camb). 2013; 49:2136-38.

297. Edmonds Y, Milstien S, Spiegel S. Development of smallmolecule inhibitors of sphingosine-1-phosphate signaling. Pharmacol Ther. 2011; 132:352-60.

298. French KJ, Zhuang Y, Maines LW, Gao P, Wang W, Beljanski V, Upson JJ, Green CL, Keller SN, Smith CD. Pharmacology and antitumor activity of ABC294640, a selective inhibitor of sphingosine kinase-2. J Pharmacol Exp Ther. 2010; 333:129-39.

299. Kim JW, Kim YW, Inagaki Y, Hwang YA, Mitsutake S, Ryu YW, Lee WK, Ha HJ, Park CS, Igarashi Y. Synthesis and evaluation of sphingoid analogs as inhibitors of sphingosine kinases. Bioorg Med Chem. 2005; 13:3475-85.

300. Kharel Y, Morris EA, Congdon MD, Thorpe SB, Tomsig JL, Santos WL, Lynch KR. Sphingosine Kinase 2 Inhibition and Blood Sphingosine 1-Phosphate Levels. J Pharmacol Exp Ther. 2015; 355:23-31.

301. Raje MR, Knott K, Kharel Y, Bissel P, Lynch KR, Santos WL. Design, synthesis and biological activity of sphingosine kinase 2 selective inhibitors. Bioorg Med Chem. 2012; 20:183-94.

302. Yoshimitsu Y, Oishi S, Miyagaki J, Inuki S, Ohno H, Fujii N. Pachastrissamine (jaspine B) and its stereoisomers inhibit sphingosine kinases and atypical protein kinase $\mathrm{C}$. Bioorg Med Chem. 2011; 19:5402-08.

303. Aurelio L, Scullino CV, Pitman MR, Sexton A, Oliver
V, Davies L, Rebello RJ, Furic L, Creek DJ, Pitson SM, Flynn BL. From sphingosine kinase to dihydroceramide desaturase: a structure-activity relationship (sar) study of the enzyme inhibitory and anticancer activity of 4-((4-(4-chlorophenyl)thiazol-2-yl)amino)phenol (ski-ii). J Med Chem. 2016; 59:965-84.

304. Brinkmann V, Billich A, Baumruker T, Heining P, Schmouder R, Francis G, Aradhye S, Burtin P. Fingolimod (FTY720): discovery and development of an oral drug to treat multiple sclerosis. Nat Rev Drug Discov. 2010; 9:88397.

305. Saddoughi SA, Gencer S, Peterson YK, Ward KE, Mukhopadhyay A, Oaks J, Bielawski J, Szulc ZM, Thomas RJ, Selvam SP, Senkal CE, Garrett-Mayer E, De Palma RM, et al. Sphingosine analogue drug FTY720 targets I2PP2A/SET and mediates lung tumour suppression via activation of PP2A-RIPK1-dependent necroptosis. EMBO Mol Med. 2013; 5:105-21.

306. Mandala S, Hajdu R, Bergstrom J, Quackenbush E, Xie J, Milligan J, Thornton R, Shei GJ, Card D, Keohane C, Rosenbach M, Hale J, Lynch CL, et al. Alteration of lymphocyte trafficking by sphingosine-1-phosphate receptor agonists. Science. 2002; 296:346-49.

307. Lee H, Deng J, Kujawski M, Yang C, Liu Y, Herrmann A, Kortylewski M, Horne D, Somlo G, Forman S, Jove $\mathrm{R}, \mathrm{Yu} \mathrm{H}$. STAT3-induced S1PR1 expression is crucial for persistent STAT3 activation in tumors. Nat Med. 2010; 16:1421-28.

308. Scuto A, Kujawski M, Kowolik C, Krymskaya L, Wang L, Weiss LM, Digiusto D, Yu H, Forman S, Jove R. STAT3 inhibition is a therapeutic strategy for ABC-like diffuse large B-cell lymphoma. Cancer Res. 2011; 71:3182-88.

309. Nishi T, Miyazaki S, Takemoto T, Suzuki K, Iio Y, Nakajima K, Ohnuki T, Kawase Y, Nara F, Inaba S, Izumi T, Yuita H, Oshima K, et al. Discovery of CS-0777: A Potent, Selective, and Orally Active S1P1 Agonist. ACS Med Chem Lett. 2011; 2:368-72.

310. Sanada Y, Mizushima T, Kai Y, Nishimura J, Hagiya H, Kurata H, Mizuno H, Uejima E, Ito T. Therapeutic effects of novel sphingosine-1-phosphate receptor agonist W-061 in murine DSS colitis. PLoS One. 2011; 6:e23933.

311. Komiya T, Sato K, Shioya H, Inagaki Y, Hagiya H, Kozaki R, Imai M, Takada Y, Maeda T, Kurata H, Kurono M, Suzuki R, Otsuki K, et al. Efficacy and immunomodulatory actions of ONO-4641, a novel selective agonist for sphingosine 1-phosphate receptors 1 and 5, in preclinical models of multiple sclerosis. Clin Exp Immunol. 2013; 171:54-62.

312. Gergely P, Nuesslein-Hildesheim B, Guerini D, Brinkmann V, Traebert M, Bruns C, Pan S, Gray NS, Hinterding K, Cooke NG, Groenewegen A, Vitaliti A, Sing T, et al. The selective sphingosine 1-phosphate receptor modulator BAF312 redirects lymphocyte distribution and has speciesspecific effects on heart rate. Br J Pharmacol. 2012; 167:1035-47. 
313. Lien YH, Yong KC, Cho C, Igarashi S, Lai LW. S1P(1)selective agonist, SEW2871, ameliorates ischemic acute renal failure. Kidney Int. 2006; 69:1601-08.

314. Jo E, Sanna MG, Gonzalez-Cabrera PJ, Thangada S, Tigyi G, Osborne DA, Hla T, Parrill AL, Rosen H. S1P1-selective in vivo-active agonists from high-throughput screening: off-the-shelf chemical probes of receptor interactions, signaling, and fate. Chem Biol. 2005; 12:703-15.

315. Zhang ZY, Zhang Z, Zug C, Nuesslein-Hildesheim B, Leppert D, Schluesener HJ. AUY954, a selective S1P(1) modulator, prevents experimental autoimmune neuritis. J Neuroimmunol. 2009; 216:59-65.

316. Galicia-Rosas G, Pikor N, Schwartz JA, Rojas O, Jian A, Summers-Deluca L, Ostrowski M, Nuesslein-Hildesheim B, Gommerman JL. A sphingosine-1-phosphate receptor 1-directed agonist reduces central nervous system inflammation in a plasmacytoid dendritic cell-dependent manner. J Immunol. 2012; 189:3700-06.

317. Poti F, Costa S, Bergonzini V, Galletti M, Pignatti E, Weber C, Simoni M, Nofer JR. Effect of sphingosine 1-phosphate (S1P) receptor agonists FTY720 and CYM5442 on atherosclerosis development in LDL receptor deficient (LDL-R $\square / \square$ ) mice. Vascul Pharmacol. 2012; 57:56-64.

318. Shimizu H, Takahashi M, Kaneko T, Murakami T, Hakamata Y, Kudou S, Kishi T, Fukuchi K, Iwanami S, Kuriyama K, Yasue T, Enosawa S, Matsumoto K, et al. KRP-203, a novel synthetic immunosuppressant, prolongs graft survival and attenuates chronic rejection in rat skin and heart allografts. Circulation. 2005; 111:222-29.

319. Brinkmann V, Davis MD, Heise CE, Albert R, Cottens S, Hof R, Bruns C, Prieschl E, Baumruker T, Hiestand P, Foster CA, Zollinger M, Lynch KR. The immune modulator FTY720 targets sphingosine 1-phosphate receptors. J Biol Chem. 2002; 277:21453-57.

320. Marsolais D, Hahm B, Walsh KB, Edelmann KH, McGavern D, Hatta Y, Kawaoka Y, Rosen H, Oldstone MB. A critical role for the sphingosine analog AAL-R in dampening the cytokine response during influenza virus infection. Proc Natl Acad Sci USA. 2009; 106:1560-65.

321. Gonzalez-Cabrera PJ, Jo E, Sanna MG, Brown S, Leaf N, Marsolais D, Schaeffer MT, Chapman J, Cameron M, Guerrero M, Roberts E, Rosen H. Full pharmacological efficacy of a novel S1P1 agonist that does not require S1P-like headgroup interactions. Mol Pharmacol. 2008; 74:1308-18.

322. Gonzalez-Cabrera PJ, Cahalan SM, Nguyen N, Sarkisyan G, Leaf NB, Cameron MD, Kago T, Rosen H. S1P(1) receptor modulation with cyclical recovery from lymphopenia ameliorates mouse model of multiple sclerosis. Mol Pharmacol. 2012; 81:166-74.

323. Clemens JJ, Davis MD, Lynch KR, Macdonald TL. Synthesis of benzimidazole based analogues of sphingosine1-phosphate: discovery of potent, subtype-selective S1P4 receptor agonists. Bioorg Med Chem Lett. 2004; 14:490306.
324. Ota H, Beutz MA, Ito M, Abe K, Oka M, McMurtry IF. $\mathrm{S} 1 \mathrm{P}(4)$ receptor mediates $\mathrm{S} 1 \mathrm{P}$-induced vasoconstriction in normotensive and hypertensive rat lungs. Pulm Circ. 2011; $1: 399-404$.

325. Song J, Hagiya H, Kurata H, Mizuno H, Ito T. Prevention of GVHD and graft rejection by a new S1P receptor agonist, W-061, in rat small bowel transplantation. Transpl Immunol. 2012; 26:163-70.

326. Herr DR, Reolo MJ, Peh YX, Wang W, Lee CW, Rivera R, Paterson IC, Chun J. Sphingosine 1-phosphate receptor 2 (S1P2) attenuates reactive oxygen species formation and inhibits cell death: implications for otoprotective therapy. Sci Rep. 2016; 6:24541.

327. Davis MD, Clemens JJ, Macdonald TL, Lynch KR. Sphingosine 1-phosphate analogs as receptor antagonists. J Biol Chem. 2005; 280:9833-41.

328. Fujii Y, Hirayama T, Ohtake H, Ono N, Inoue T, Sakurai T, Takayama T, Matsumoto K, Tsukahara N, Hidano S, Harima N, Nakazawa K, Igarashi Y, et al. Amelioration of collagen-induced arthritis by a novel S1P1 antagonist with immunomodulatory activities. J Immunol. 2012; 188:20615.

329. Quancard J, Bollbuck B, Janser P, Angst D, Berst F, Buehlmayer P, Streiff M, Beerli C, Brinkmann V, Guerini D, Smith PA, Seabrook TJ, Traebert M, et al. A potent and selective S1P(1) antagonist with efficacy in experimental autoimmune encephalomyelitis. Chem Biol. 2012; 19:1142-51.

330. Tarrasón G, Aulí M, Mustafa S, Dolgachev V, Domènech MT, Prats N, Domínguez M, López R, Aguilar N, Calbet M, Pont M, Milligan G, Kunkel SL, et al. The sphingosine1-phosphate receptor-1 antagonist, W146, causes early and short-lasting peripheral blood lymphopenia in mice. Int Immunopharmacol. 2011; 11:1773-79.

331. Ikeda H, Satoh H, Yanase M, Inoue Y, Tomiya T, Arai M, Tejima K, Nagashima K, Maekawa H, Yahagi N, Yatomi Y, Sakurada S, Takuwa Y, et al. Antiproliferative property of sphingosine 1-phosphate in rat hepatocytes involves activation of Rho via Edg-5. Gastroenterology. 2003; 124:459-69.

332. Kunkel GT, Maceyka M, Milstien S, Spiegel S. Targeting the sphingosine-1-phosphate axis in cancer, inflammation and beyond. Nat Rev Drug Discov. 2013; 12:688-702.

333. Murate T, Banno Y, T-Koizumi K, Watanabe K, Mori N, Wada A, Igarashi Y, Takagi A, Kojima T, Asano H, Akao Y, Yoshida S, Saito H, et al. Cell type-specific localization of sphingosine kinase 1a in human tissues. J Histochem Cytochem. 2001; 49:845-55.

334. Kihara A, Anada Y, Igarashi Y. Mouse sphingosine kinase isoforms SPHK1a and SPHK1b differ in enzymatic traits including stability, localization, modification, and oligomerization. J Biol Chem. 2006; 281:4532-39.

335. Nava VE, Lacana E, Poulton S, Liu H, Sugiura M, Kono K, Milstien S, Kohama T, Spiegel S. Functional 
characterization of human sphingosine kinase-1. FEBS Lett. 2000; 473:81-84

336. Maceyka M, Spiegel S. Sphingolipid metabolites in inflammatory disease. Nature. 2014; 510:58-67.

337. Okada T, Ding G, Sonoda H, Kajimoto T, Haga Y, Khosrowbeygi A, Gao S, Miwa N, Jahangeer S, Nakamura $\mathrm{S}$. Involvement of N-terminal-extended form of sphingosine kinase 2 in serum-dependent regulation of cell proliferation and apoptosis. J Biol Chem. 2005; 280:36318-25.

338. Shirai K, Kaneshiro T, Wada M, Furuya H, Bielawski J, Hannun YA, Obeid LM, Ogretmen B, Kawamori T. A role of sphingosine kinase 1 in head and neck carcinogenesis. Cancer Prev Res (Phila). 2011; 4:454-62.
339. Nunes J, Naymark M, Sauer L, Muhammad A, Keun H, Sturge J, Stebbing J, Waxman J, Pchejetski D. Circulating sphingosine-1-phosphate and erythrocyte sphingosine kinase-1 activity as novel biomarkers for early prostate cancer detection. Br J Cancer. 2012; 106:909-15.

340. Sarkar S, Maceyka M, Hait NC, Paugh SW, Sankala H, Milstien S, Spiegel S. Sphingosine kinase 1 is required for migration, proliferation and survival of MCF-7 human breast cancer cells. FEBS Lett. 2005; 579:5313-17.

341. Van Brocklyn JR. Sphingolipid signaling pathways as potential therapeutic targets in gliomas. Mini Rev Med Chem. 2007; 7:984-90. 